CHARACTERIZATION OF UPPER PALAEOZOIC ORGANIC-RICH UNITS IN SVALBARD IMPLICATIONS FOR THE PETROLEUM SYSTEMS OF THE NORWEGIAN BARENTS SHELF

Nicolaisen, J. B.; Elvebakk, G.; Ahokas, J.; Bojesen-Koefoed, J. A.; Olaussen, S.; Rinna, J.; Skeie, J. E.; Stemmerik, L.

Published in:

Journal of Petroleum Geology

DOI:

10.1111/.jpg.12724

Publication date:

2019

Document version

Publisher's PDF, also known as Version of record

Document license:

CC BY

Citation for published version (APA):

Nicolaisen, J. B., Elvebakk, G., Ahokas, J., Bojesen-Koefoed, J. A., Olaussen, S., Rinna, J., Skeie, J. E., \& Stemmerik, L. (2019). CHARACTERIZATION OF UPPER PALAEOZOIC ORGANIC-RICH UNITS IN SVALBARD: IMPLICATIONS FOR THE PETROLEUM SYSTEMS OF THE NORWEGIAN BARENTS SHELF. Journal of Petroleum Geology, 42(1), 59-78. https://doi.org/10.1111/jpg.12724 


\title{
CHARACTERIZATION OF UPPER PALAEOZOIC ORGANIC-RICH UNITS IN SVALBARD: IMPLICATIONS FOR THE PETROLEUM SYSTEMS OF THE NORWEGIAN BARENTS SHELF
}

\author{
J. B. Nicolaisen ${ }^{\mathrm{a}, \mathrm{e}}$, , G. Elvebakk ${ }^{\mathrm{b}}$, J. Ahokasc, J. A. Bojesen- \\ Koefoed $^{d}$, S. Olaussen ${ }^{\text {, J. J. Rinna }}{ }^{c}$, J. E. Skeie ${ }^{c}$ and L. Stemmerik ${ }^{a, e}$
}

Recent discoveries of hydrocarbons along the western margin of the Norwegian Barents Shelf have emphasised the need for a better understanding of the source rock potential of the Upper Palaeozoic succession. In this study, a comprehensive set of organic geochemical data have been collected from the Carboniferous - Permian interval outcropping on Svalbard in order to re-assess the offshore potential. Four stratigraphic levels with organic-rich facies have been identified: (i) Lower Carboniferous (Mississippian) fluvio-lacustrine intervals with TOC between I and 75 wt.\% and a cumulative organic-rich section more than $100 \mathrm{~m}$ thick; (ii) Upper Carboniferous (Pennsylvanian) evaporite-associated marine shales and organicrich carbonates with TOC up to 20 wt.\%; (iii) a widespread lowermost Permian organic-rich carbonate unit, 2-10 m thick, with I-10 wt. \% TOC; and (iv) Lower Permian organic-rich marine shales with an average TOC content of $10 \mathrm{wt} . \%$.

Petroleum can potentially be tied to organic-rich facies at formation level based on the gammacerane index, $\delta^{13} \mathrm{C}$ of the aromatic fraction and/or the $\mathrm{Pr} / \mathrm{Ph}$ ratio. Relatively heavy $\delta^{13} \mathrm{C}$ values, a low gammacerane index and high Pr/Ph ratios characterize Lower Carboniferous non-marine sediments, whereas evaporite-associated facies have lighter $\delta^{13} \mathrm{C}$, a higher gammacerane index and lower Pr/Ph ratios.

\section{INTRODUCTION}

The Norwegian part of the Barents Shelf covers an area of more than $300,000 \mathrm{~km}^{2}$ and is still considered a frontier petroleum province, with only 145 exploration wells drilled and two fields in production. In a recent update, the Norwegian authorities estimated that more than $60 \%$ of the undiscovered petroleum resources

aNatural History Museum of Denmark, University of Copenhagen, Denmark.

${ }^{\mathrm{b}}$ Geo-Moski AS, Norway.

'Aker BP, Norway.

dGEUS, Geological Survey of Denmark and Greenland, Denmark.

eUNIS, University Centre in Svalbard, Norway.

* corresponding author, email: jakob.kristensen@snm.ku.dk on the Norwegian continental shelf are located in the Barents Sea, and that $60-80 \%$ of those are in Triassic and older stratigraphic units (NPD, 2018).

The Upper Palaeozoic succession in the western Barents Sea consists of four second-order depositional sequences, each corresponding to a group in the lithostratigraphic scheme for the Norwegian Barents Sea (Figs 1, 2; Larssen et al., 2005). The four-fold division of the succession reflects long (15-50 Ma) periods of relatively stable depositional conditions on the central Pangean shelf separated by abrupt intervals of change (Stemmerik and Worsley, 2005). The Lower Carboniferous Billefjorden Group (Fig. 2) is up to 600

Key words: Norway, Barents Sea, Svalbard, Spitsbergen, Upper Palaeozoic, source rocks, petroleum, geochemistry, gammacerane index, biomarkers, isotope ratios. 


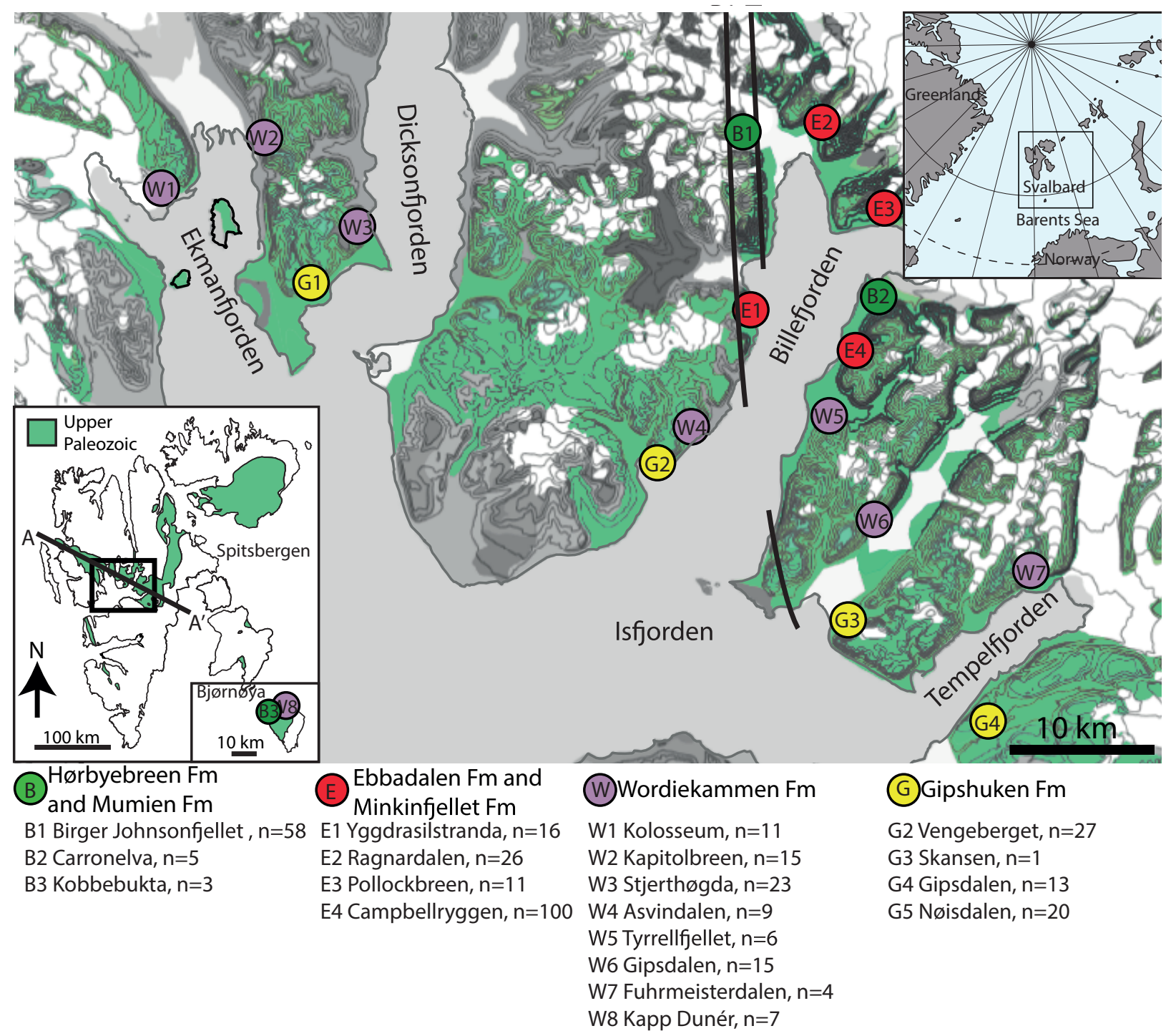

Fig. I. Map of sample locations in Central Svalbard and on Bjørnøya.The Billefjorden Fault Zone (BFZ) is marked by black lines. Sample sites are marked by circles. The number of analyzed samples at each site is summarised at the bottom of the figure.

$m$ thick and is dominated by fluvial deposits including widespread coal layers and corresponds to deposition in a humid tropical climate (van Koeverden and Karlsen, 2011). The up to $1500 \mathrm{~m}$ thick mid-Carboniferous Lower Permian Gipsdalen Group consists of a lower, continental to marginal-marine syn-rift succession of coarse-grained siliciclastics and evaporites, and a regionally widespread upper interval of warm-water carbonates. Deposition took place in in a warm and arid setting (Stemmerik and Worsley, 2005). The overlying Lower Permian Bjarmeland Group is up to $500 \mathrm{~m}$ thick and is composed of cool-water carbonates and interbedded marine shales deposited in a temperate setting. The up to $900 \mathrm{~m}$ thick Lower - Upper Permian Tempelfjorden Group is characterized by spiculites and silicified limestones deposited in deeper and cooler shelfal environments (Blomeier et al., 2011).

Three generalized exploration models have been proposed for the Upper Palaeozoic succession on the western Barents Shelf based on the integration of offshore data with studies of outcrops of the timeequivalent succession on Svalbard in the uplifted NW margin of the Barents Shelf (Fig. 1) (NPD, 2018). Models with Lower Carboniferous Billefjorden fluvial sandstones and Upper Carboniferous - Lower Permian Gipsdalen warm-water carbonates are so far unconfirmed. However, recent discoveries of petroleum in karstified Permian carbonates and spiculites in the Gohta and Alta areas along the western margin of the Norwegian Barents Shelf have confirmed the significance of these stratigraphic intervals as petroleum reservoirs, and have emphasised the need for a better understanding of the petroleum source potential of the Upper Palaeozoic succession in this part of the Arctic.

Play models with Upper Carboniferous - Permian carbonates and spiculites as reservoirs depend on the assumed presence of intra-platform source rocks in the 
A
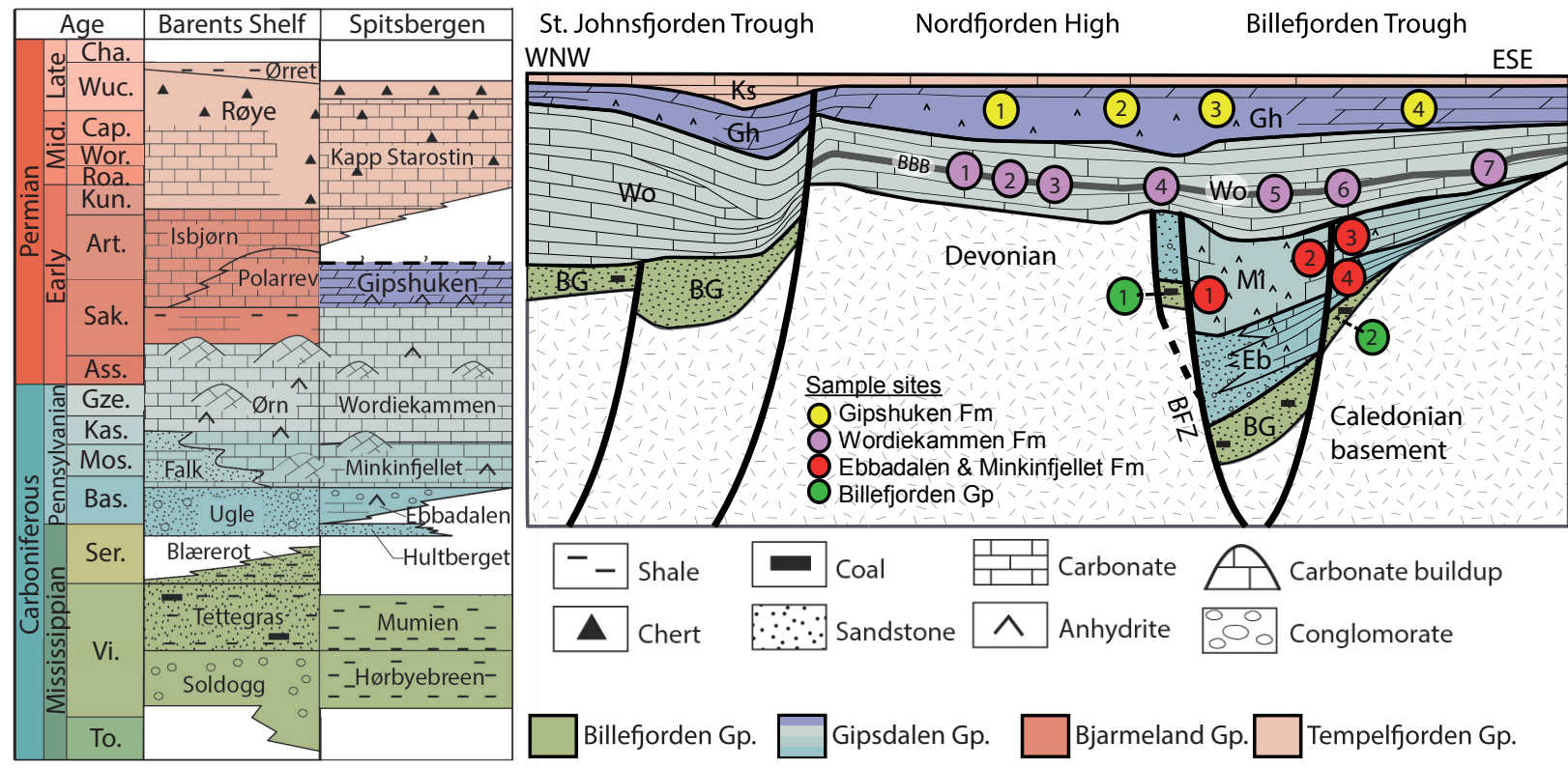

Fig. 2 (left). Stratigraphy of Spitsbergen and the Barents Shelf; and (right) simplified west-east cross-section across central Spitsbergen A-A' (profile location in Fig. I inset). The cross-section shows the major tectonic elements, the lithostratigraphic units and the dominant lithologies. BG: Billefjorden Group, Eb, Ebbadalen Formation, Mi: Minkinfjellet Formation,Wo:Wordiekammen Formation, BBB: Brucebyen Beds, Gh: Gipshuken Formation, Ks: Kapp Starostin Formation, BFZ: Billefjorden Fault Zone (modified from Hüneke et al., 200 I).

Norwegian Barents Shelf. However, their presence is poorly constrained and very little information exists about their quality. The only Upper Palaeozoic interval with documented petroleum source potential is the coal-bearing Billefjorden Group at the base of the succession. This interval has been studied in outcrops in Svalbard (Figs 1, 2) (Abdullah et al., 1988; van Koeverden and Karlsen, 2011). From outcrop studies on Svalbard, it has also been suggested that an organicrich interval in the Upper Carboniferous - Lower Permian carbonate platform succession may have petroleum source potential.

In this study, a comprehensive set of organic geochemical data, including biomarker and isotope data, have been collected from the Carboniferous - Lower Permian succession in Svalbard, and has been integrated with analyses of depositional and tectonic settings to provide a better understanding of the source potential in the adjacent offshore areas. Focus was on organic-rich intervals in the nonmarine Billefjorden Group and the marine parts of the overlying Gipsdalen Group, particularly successions of interbedded carbonates and $\mathrm{CaSO}_{4}$-rich evaporites, since they were easy to identify seismically on the shelf. Three stratigraphic levels with source-rock potential in the marine, mid-Carboniferous to Lower Permian Gipsdalen Group have been identified and characterized, of which two are new. The marine organic-rich facies were deposited in a broad range of shallow-shelf environments, from semi-arid, evaporite-associated to open-marine, and accordingly geochemical fingerprinting can be used to distinguish oil originating from the different types of marine facies.

\section{GEOLOGICAL SETTING}

Outcropping rocks on the Svalbard archipelago are widely used as analogues for the deeply-buried equivalents in offshore areas of the western Barents Shelf (Figs 1, 2) (e.g. Abay et al., 2017; Jafarian et al., 2017). During the Late Palaeozoic, the Barents Shelf formed part of a large-scale, east-west oriented continental shelf along the northern margin of Pangea extending westwards across northern Greenland to Arctic Canada and eastwards to the Timan-Pechora Basin in Arctic Russia. The entire region drifted northwards during the Carboniferous and Permian and, in concert with an ongoing transgression from the NE, resulted in overall shifts in depositional environments as reflected in the lithostratigraphic division of the succession (Stemmerik, 2000; Stemmerik and Worsley, 2005).

Early Carboniferous (Tournaisian-Viséan) deposition occurred in continental basins in a warm and humid climate. Fluvial sandstones, coals and lacustrine sediments of the Billefjorden Group were deposited in extensional basins across the western Barents Shelf including Svalbard (Steel and Worsley, 1984). To the east, these sediments pass into marine deposits in the Russian sector of the Barents Shelf (Stemmerik, 2000). 
Table I. Applied methods and number of samples analysed in the present study.

\begin{tabular}{|c|c|c|c|c|c|c|}
\hline Group/Formation & $\begin{array}{l}\text { Rock-Eval } \\
\text { pyrolysis }\end{array}$ & $\begin{array}{c}\text { Extraction of organic } \\
\text { material (EOM) }\end{array}$ & $\begin{array}{l}\text { MS of aromatic and } \\
\text { saturated fractions }\end{array}$ & GC & GC/MS & PyGC \\
\hline Kapp Starostin Formation & 22 & - & - & - & - & - \\
\hline $\begin{array}{c}\text { Gipshuken Formation } \\
\text { Marine }\end{array}$ & 20 & 9 & 9 & 9 & 9 & 3 \\
\hline $\begin{array}{c}\text { Gipshuken Formation } \\
\text { Evaporitic }\end{array}$ & 19 & 12 & 12 & 12 & 12 & - \\
\hline Wordiekammen Formation & 93 & 25 & 25 & 25 & 25 & 4 \\
\hline $\begin{array}{l}\text { Ebbadalen Formation and } \\
\text { Minkinfjellet Formation }\end{array}$ & 175 & 36 & 36 & 36 & 36 & 3 \\
\hline Mumien Formation & 21 & 17 & 17 & 17 & 17 & 5 \\
\hline Hørbyebreen Formation & 46 & 11 & 11 & 11 & 11 & 5 \\
\hline
\end{tabular}

Following early Serphukovian uplift and erosion, subsidence began in narrow half-grabens during the late Serpukhovian, and the region was transgressed in the Bashkirian. The climate was warm and arid, and the ongoing transgression, modulated by high frequency sea-level changes related to the Gondwanaland glaciations, resulted in the deposition of the Gipsdalen Group sedimentary succession (e.g. Stemmerik, 2000; Larssen et al., 2005). At the base of the succession are continental conglomerates and sandstones, followed by interbedded marine evaporites and carbonates, and ending with widespread open-marine warm-water carbonates including localized build-ups during the Late Carboniferous to Early Permian. During the middle Permian, the climate gradually became cooler and deposition of cool-water carbonates and marine shales, and then spiculites and cool-water carbonates, dominated the later parts of the Permian (e.g. Steel and Worsley, 1984; Larssen et al., 2005).

On Spitsbergen, the largest island in Svalbard, extension on north-south oriented faults resulted in a series of westwards tilted half-grabens (Figs 1,2). The Gipsdalen Group syn-rift deposits of the Ebbadalen and Minkinfjellet Formations (Fig. 2) were deposited in the rapidly-subsiding Billefjorden and St. Johnsfjorden Troughs (Steel and Worsley, 1984). As tectonic activity ceased during the latest Carboniferous, the depositional area expanded and the overlying Wordiekammen and Gipshuken Formations (Fig. 2) are characterized by more widespread, stable platform carbonates with less thickness and facies variations.

The Carboniferous and Permian succession in central Spitsbergen has an accumulated thickness of approximately $2000 \mathrm{~m}$ in the troughs and $750 \mathrm{~m}$ on the highs (Braathen et al., 2011; Steel and Worsley, 1984; Dallmann et al., 1999). In central and eastern Spitsbergen, to the north and east of the Central Tertiary Basin, maximum burial occurred during the Early Cretaceous (Albian) with an overburden of approximately $2000 \mathrm{~m}$ of Mesozoic sediments (Mørk and Worsley, 2006; Ogata et al., 2012; Marshal et al., 2015). In the West Spitsbergen fold-and-thrust belt, and in the Central Tertiary Basin, maximum burial occurred during the Oligocene, prior to the start of extension between Svalbard and Greenland (Nøttvedt et al., 1993). Approximately $2000 \mathrm{~m}$ of Paleogene sediments are preserved in the Central Tertiary Basin, and Marshall et al. (2015) estimated that an additional $1000 \mathrm{~m}$ of sediments were removed during Pliocene - Quaternary uplift of Svalbard. The present-day geothermal gradient is $33-40{ }^{\circ} \mathrm{C} / \mathrm{km}$ in the Central Tertiary Basin (Braathen et al., 2012), and may have been up to $50{ }^{\circ} \mathrm{C} / \mathrm{km}$ during maximum burial (e.g. Marshall et al., 2015).

\section{MATERIALS AND METHODS}

\section{Sampling and sedimentological logging}

Sedimentological logging and sampling were carried out using standard techniques during winter and summer field work. Sample locations on Spitsbergen were chosen to ensure the best possible geographical and stratigraphic coverage of the Upper Palaeozoic succession, with a focus on the Billefjorden Trough and the Nordfjorden High in central Spitsbergen (Figs 1,2).

Sampling focused on dark grey - black, finegrained siliciclastics and carbonates. For thinner beds, the entire unit was sampled. Beds thicker than $50 \mathrm{~cm}$ were sampled at the top and bottom, and beds thicker than $1 \mathrm{~m}$ were sampled for every $50 \mathrm{~cm}$, including the base and top. A total of 395 samples were analyzed using Rock-Eval pyrolysis for source rock screening, of which 110 samples were analyzed in more detail (Table 1).

\section{Billefjorden Group (Lower Carboniferous)}

The majority of the analyzed samples from this stratigraphic interval (46 out of 65) were recovered 


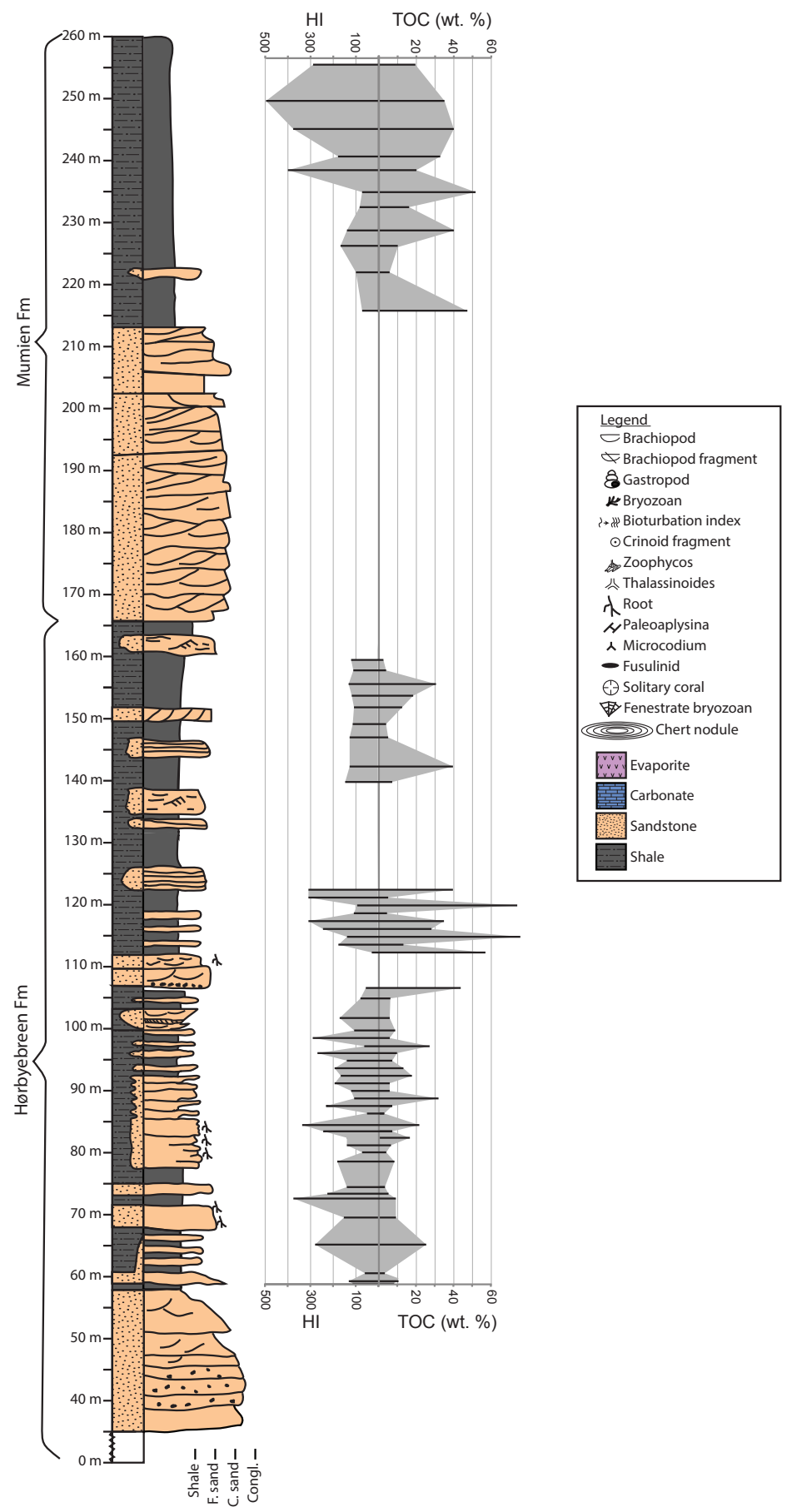

Fig. 3. Sedimentological log of the Hørbyebreen and Mumien Formations at Birger Johnsonfjellet showing stratigraphic distribution of screening data. Compiled using information from Gjelberg (1984). For location, see Fig. I.

from the Hørbybreen and Mumien Formations in a ca. $260 \mathrm{~m}$ long section at Birger Johnsonfjellet (B, Fig. 1; logged section in Fig. 3). Additional samples from adjacent localities along Billefjorden were analyzed together with a single sample from Bjørnøya, $450 \mathrm{~km}$ to the south, to investigate regional variations.

\section{Gipsdalen Group (mid-Carboniferous -}

Lower Permian)

Material from the Bashkirian-Moscovian syn-rift succession was collected in sections in the Billefjorden
Trough (Figs 1,2). Material from the marine Bashkirian Trikolorfjellet Member (Ebbadalen Formation) included 33 samples of laminated, organic-rich intervals within $\mathrm{CaSO}_{4}$-evaporites and thin organicrich shales at the bases and tops of carbonate beds. This material was collected from two sections, each up to $200 \mathrm{~m}$ thick, in northernmost Billefjorden (E2 and E3, Fig. 1). At this locality, the Trikolorfjellet Member consists of interbedded $1-10 \mathrm{~m}$ thick marine carbonates and $\mathrm{CaSO}_{4}$-evaporites with rare intercalations of continental sabkha deposits (red siltstones with gypsum 


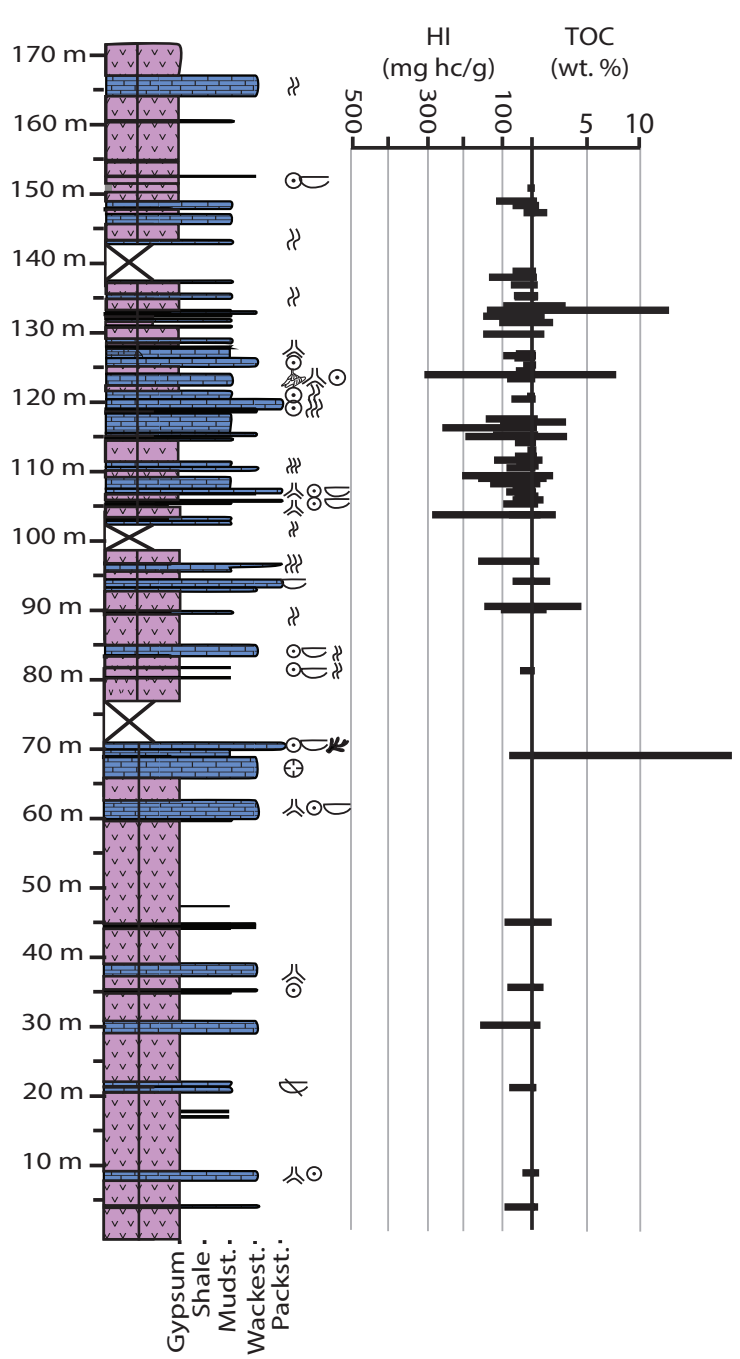

Fig. 4. Sedimentological log and screening data through the Minkinfjellet Formation. For location, see E4 in Fig. I. For legend, see Fig. 3.

nodules). Samples from the Moscovian Minkinfjellet Formation consist of organic-rich laminae within evaporites, organic-rich shales deposited between carbonates and evaporites, and organic-rich carbonate mudstones; the great majority were carbonates (Fig. 4). Most of the samples, 61 out of 118 , were collected from a $170 \mathrm{~m}$ thick section of interbedded marine carbonates and evaporites at Campellryggen along the east shore of Billefjorden (E4, Fig. 1). Additional samples were collected at outcrops just to the south and north of this location ( $n=39)$, at Yggdrasilstranda along the western shore of Billefjorden $(\mathrm{n}=16)$, and in Ragnardalen ( $\mathrm{n}$ $=26$ ), north of Billefjorden (Fig. 1).

The 2-12 m thick uppermost Gzelian - lowermost Asselian Brucebyen Beds (Fig. 5) form a distinctive interval within an up to $350 \mathrm{~m}$ thick succession of cyclic warm-water carbonates. These characterize the Moscovian-Sakmarian Wordiekammen Formation platform carbonates on Spitsbergen (e.g. Ahlborn and

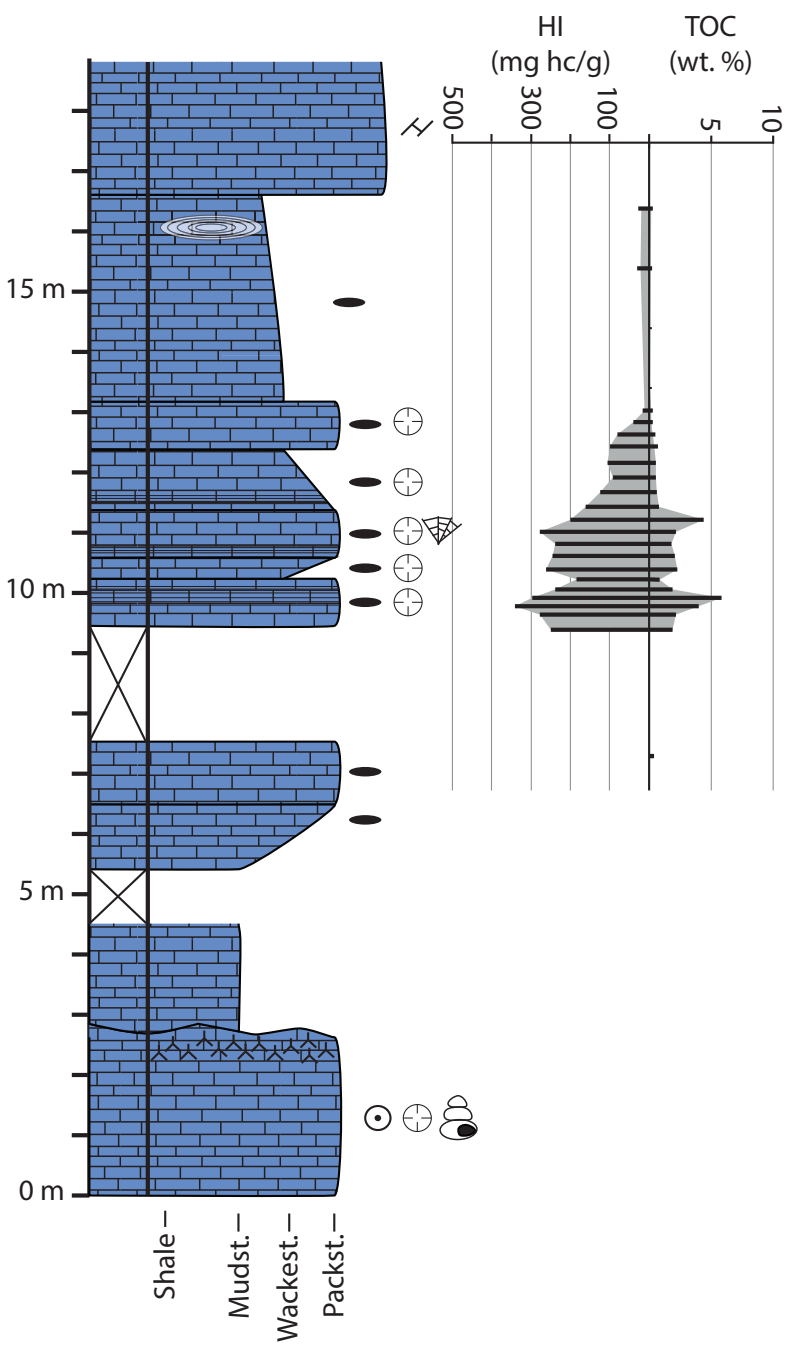

Fig. 5. Log and screening data through the Brucebyen Beds, Wordiekammen Formation, at the type section. For location, see W5 in Fig. I. For legend, see Fig. 3.

Stemmerik, 2015). A total of 90 samples were collected from seven localities along a $70 \mathrm{~km}$ east-west transect across central Spitsbergen from Kolosseum in the west to Fuhrmeisterdalen in the east (Fig. 1). The most densely sampled section was W3 in the west (Fig. 5). A few additional samples from similar facies were collected at Bjørnøya (Kapp Duner Formation) (Fig. 1). All the samples were composed of carbonates.

Material from the Lower Permian Gipshuken Formation consisted of shales deposited in two different settings. Shale samples from the lower Vengeberget Member are associated with $\mathrm{CaSO}_{4}$-evaporites and 41 samples were collected from three localities along a transect from Ekmanfjorden to Tempelfjorden (Figs $1,2)$. In addition, shales associated with open-marine carbonates were collected from a single section at Nøisdalen, south of Tempelfjorden (Figs 1, 2). This material includes 20 samples of up to $10 \mathrm{~cm}$ thick shale beds. 


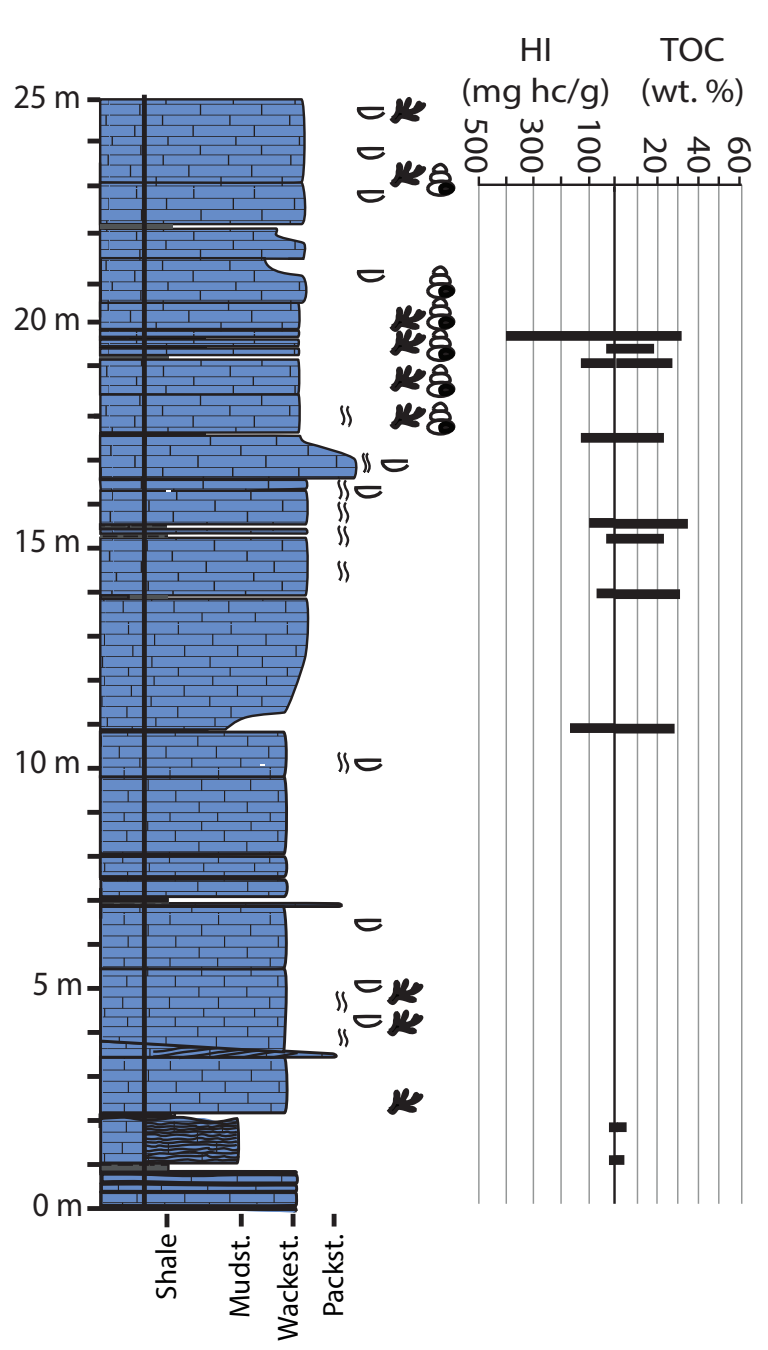

Fig. 6. Log and screening data through the marine part of the Gipshuken Formation. For location, see G4 in Fig. I. For legend, see Fig. 3.

\section{Tempelfjorden Group (Lower - Upper Permian)}

Twenty-five samples of dark marls from the lower part of the Kapp Starostin Formation were screened for organic content and HI. They show an average TOC content of $0.7 \%$ and $\mathrm{HI}$ of $67 \mathrm{mg} \mathrm{HC} / \mathrm{g} \mathrm{TOC}$, indicating that the material has no source potential. The samples were not analyzed further.

\section{Geochemical analysis}

Geochemical analyses were carried out at Applied Petroleum Technology (APT), Lillestrøm, Norway, in accordance with the guidelines described in Weiss et al. (2000). All samples were screened for their content of total organic matter (TOC) using a Leco SC-632 instrument, and analysed by Rock-Eval pyrolysis in order to determine the kerogen type, maturity and source potential. Samples for further analysis were chosen based on the screening results and analysed by gas chromatography (GC), gas chromatography- mass spectrometry (GC-MS and GC-MS-MS), and for stable carbon isotope ratios of the saturated and aromatic hydrocarbon fractions. From each formation, a few samples with source potential were analyzed using pyrolysis gas chromatography (Py-GC) in order to evaluate their ability to generate petroleum. The gas-to-oil generation index (GOGI) was calculated as $\left(\mathrm{C}_{1}-\mathrm{C}_{5}\right) /\left(\mathrm{C}_{5}-\mathrm{C}_{36}\right)$.

Samples for vitrinite reflectance were prepared and measured at the Geological Survey of Denmark and Greenland (GEUS) using standard procedures defined by ICCP and described in Bustin et al. (1989). Molybdenum concentrations were measured on selected samples of the Gipshuken Formation using an Innov X Alpha XRF analyser. The samples were powdered, filled in small glass vessels that were covered by plastic film and turned upside down, so that the XRF was measured trough the film. The results were evaluated for misleading results by visual comparison of the XRF spectrograms with the expected $\mathrm{K} \alpha$ and $\mathrm{K} \beta$ for molybdenum. Measurements lacking one of the peaks were discarded as false read-outs. Internal Innovex software was used to convert the peaks to concentrations, which were checked against a NIST-2781 standard measured every tenth sample. All standard measurements are within $3 \mathrm{ppm}$ of the expected Mo concentration.

\section{RESULTS}

\section{Billefjorden Group, Hørbybreen and Mumien Formations (Viséan)}

In the key section at Birger Johnsonfjellet (Fig. 3), the Hørbybreen Formation consists of a basal fluvial sandstone unit overlain by a $105 \mathrm{~m}$ thick heterolithic floodplain succession (c.f. Gjelberg and Steel, 1981) composed of lacustrine shales, fluvial sandstones and thin coal beds. Organic-rich shales dominate and have an accumulated thickness of approximately $70 \mathrm{~m}$, whereas the coal beds have an accumulated thickness of less than $3 \mathrm{~m}$. The overlying Mumien Formation consists of $50 \mathrm{~m}$ of stacked, fluvial channel sandstones overlain by a more than $40 \mathrm{~m}$ thick heterolithic interval dominated by organic-rich siltstones containing Botryococcus algae, interpreted to reflect deposition in shallow lacustrine environments (Abdullah et al., 1988).

In the analyzed material, TOC values range from 1 to 75 wt.\% with most samples between 3 and 10 wt.\%, and $\mathrm{HI}$ values range from 50 to $375 \mathrm{mg} \mathrm{HC} / \mathrm{g}$ TOC (Fig. 7a). The most organic-rich facies occur in the middle part of the Hørbyebreen Formation (ca. 112-123 m) and the upper part of the Mumien Formation (ca. 215-260 m) (Fig. 3). Material from the Hørbyebreen Formation follows two different trend lines in a $\mathrm{S}_{2}-\mathrm{TOC}$ plot (Fig. 7b), with one population 

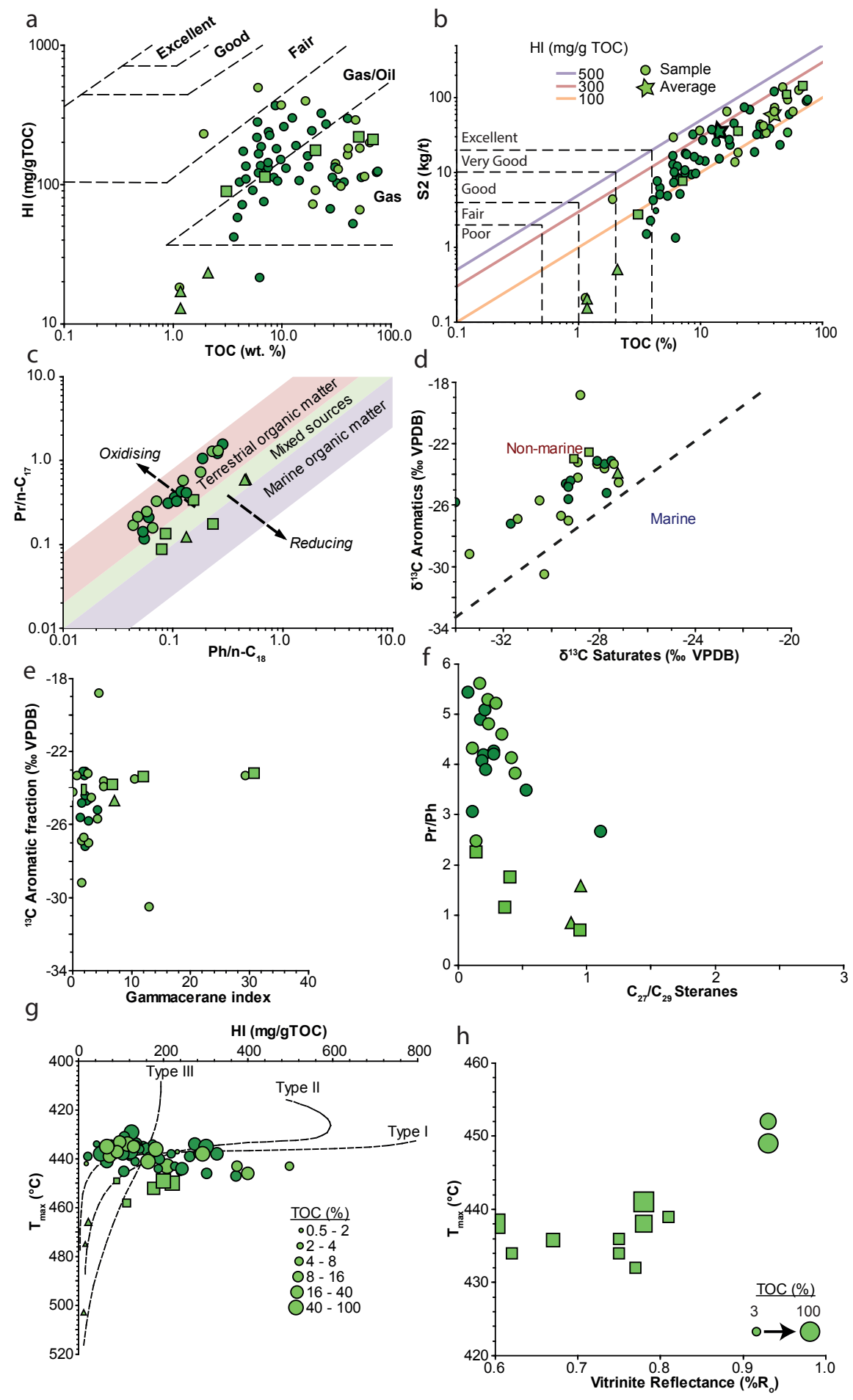

OBirger Johnsonfjellet $\triangle$ Carronelva

OHørbyebreen Fm OMumien Fm

Fig. 7. Geochemical cross-plots of samples from the Hørbyebreen and Mumien Formations. (A) Hydrogen index (HI) versus total organic carbon (TOC); note that all the samples are mature and that the initial quality of the samples would have been higher. (B) Cross-plot of $S_{2}$ versus TOC for sampled potential source rocks in Svalbard; averages for each formation are illustrated by stars. (C) Cross-plot of pristane $/\left(n-C_{17}\right)$ versus phytane $/\left(n-C_{18}\right)$; note that samples from Birger Johnsonfjellet represent footwall locations, while the sediments at Carronelva and possibly Bjørnøya were deposited within tectonically-controlled depressions (Abdullah et al., 1988). (D) Cross-plot of $\delta^{13} \mathrm{C}$ aromatic hydrocarbon fractions versus saturated hydrocarbon fraction in sample extracts. (E) Cross-plot of $\delta^{13} \mathrm{C}$ of the aromatic fraction against the gammacerane index. (F) Cross-plot of $\mathrm{C}_{27} / \mathrm{C}_{29}$ steranes versus pristane /phytane ratio. (G) Cross-plot of $\mathrm{HI}$ versus $\mathrm{T}_{\max }$ showing that most samples are within the oil window. $(H)$ Cross-plot of $T_{\max }$ versus vitrinite reflectance $\left(\% \mathbf{R}_{\mathrm{o}}\right)$ of samples from Birger Johnsonfjellet and Carronelva. 

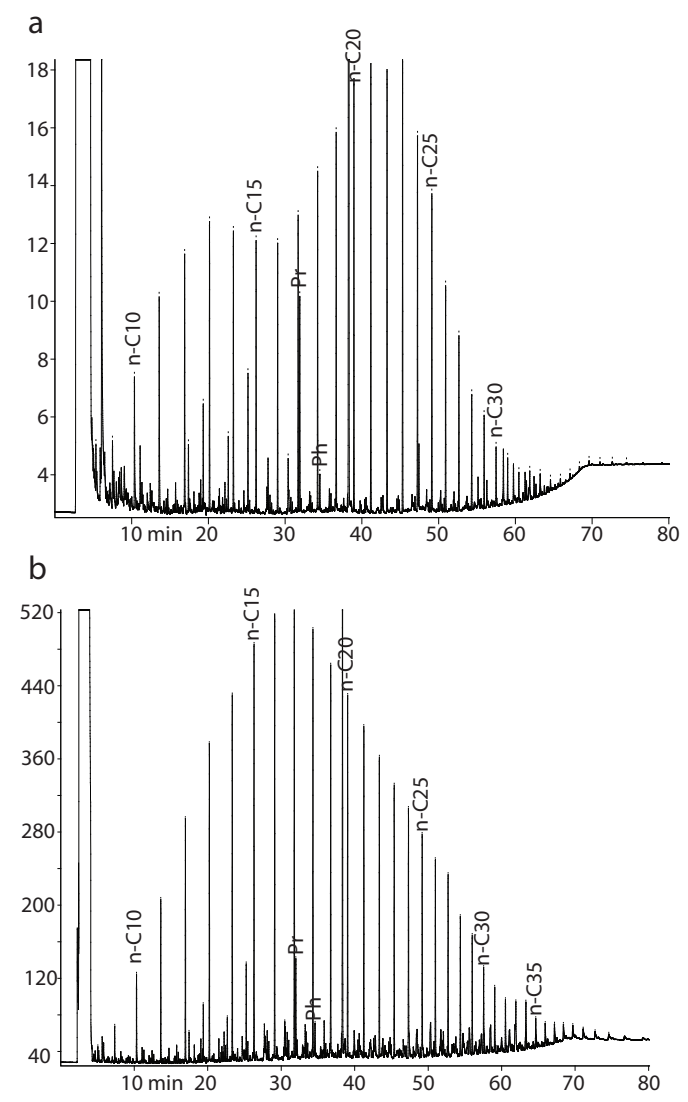

Fig. 8. (a) GC-FID chromatogram of a sample from the Mumien Formation at the Birger Johnsonfjellet site; note the bimodal $n$-alkane distribution, the odd predominance (CPI), and the waxy n-alkane distribution indicating a possible equally-mixed Type II/III source of organic matter. (b) GC-FID chromatogram of a sample from the Mumien Formation at the Carronelva location, with a unimodal front-end biased $\boldsymbol{n}$-alkane distribution indicating input to the source rock system of a more uniform marine Type II/“III" source of organic matter.

along the $\mathrm{HI}$ line at $300 \mathrm{mg} \mathrm{HC} / \mathrm{g}$ TOC and the other around the $\mathrm{HI}$ line at $100 \mathrm{mg} \mathrm{HC/g} \mathrm{TOC.}$

Most Billefjorden Group material shows a unimodal $n$-alkane distribution, dominated by longchain $n$-alkanes (Fig. 8a); less commonly the $n$-alkane distribution is bimodal (Fig. 8b). The $\mathrm{Pr} / \mathrm{Ph}$ ratio ranges from 0.8 to 5.5 , with the highest values in samples from Birger Johnsonfjellet and lower values in samples from Carronelva (Fig. 7b), east of Birger Johnsonfjellet and Kobbebukta at Bjørnøya. $\mathrm{C}_{30}$ steranes are absent from the samples (Fig. 9). In cross-plots of pristane (Pr) versus phytane $(\mathrm{Ph})$ and $\delta^{13} \mathrm{C}$ of the aromatic versus saturated hydrocarbon fractions, the material falls mainly in the terrigenous regime (Figs 7c, 7d).

The analyzed material has been buried to conditions corresponding to the oil window, with $\mathrm{T}_{\max }$ values mainly between $430^{\circ} \mathrm{C}$ and $450^{\circ} \mathrm{C}$ (Fig. $7 \mathrm{~g}$ ) (cf. Peters and Cassa, 1994). Samples from Birger Johnsonfjellet at the Nordfjorden High show vitrinite reflectance
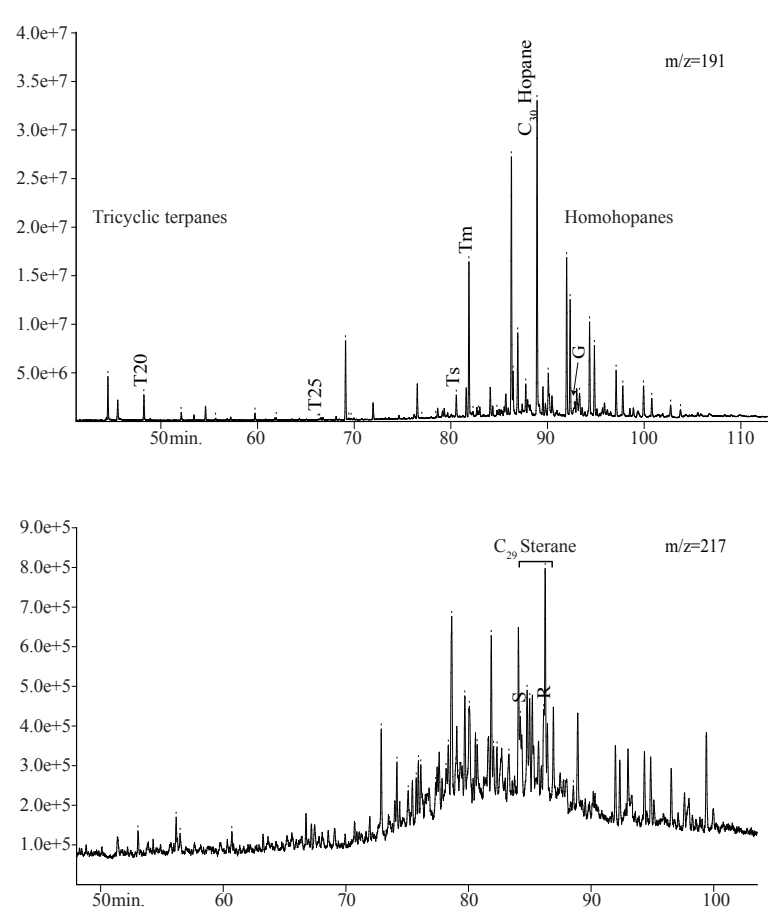

Fig. 9. GC-MS ion chromatogram $\mathrm{m} / \mathrm{z}=191$ and $\mathrm{m} / \mathrm{z}=217$ fragmentogram of a representative sample of the Mumien Formation at Birger Johnsonfjellet.

between 0.6 and $0.8 \% \mathrm{R}_{\mathrm{o}}$ and $\mathrm{T}_{\max }$ values between 430 ${ }^{\circ} \mathrm{C}$ and $440{ }^{\circ} \mathrm{C}$, while samples from Carronelva in the Billefjorden Trough yielded higher vitrinite reflectance, $0.9 \% \mathrm{R}_{\mathrm{o}}$, and $\mathrm{T}_{\max }$ of $450{ }^{\circ} \mathrm{C}$ (Fig. $7 \mathrm{~h}$ ).

\section{Gipsdalen Group, Ebbadalen and Minkinfjellet Formations (Sepukhovian - Moscovian)}

The analyzed material consists of relatively thin, organic-rich shales and carbonates interbedded with much thicker, organic-lean carbonates and evaporites in both the Trikolorfjellet Member (Ebbadalen Formation) and Minkinfjellet Formation. The organicrich laminae within the evaporites are $1-5 \mathrm{~cm}$ thick and occur throughout the succession, and constitute $1-5 \%$ of the evaporite beds. TOC values range between 0.5 and $1.5 \mathrm{wt} . \%$ and $\mathrm{HI}$ values are $40-275 \mathrm{mg} \mathrm{HC} / \mathrm{g}$ TOC, with an average of $90 \mathrm{mg} \mathrm{HC} / \mathrm{g}$ TOC (Fig. 10a). The laminated organic-rich shale facies are of similar thickness $(1-5 \mathrm{~cm})$ and occur in both the carbonateand evaporite-dominated units. They constitute around $0.5 \%$ of the succession. TOC ranges from 0.5 to 60 wt.\%, with most in the range $0.5-1.5$ wt. $\%$, and $\mathrm{HI}$ values are between 35 and $280 \mathrm{mg} \mathrm{HC} / \mathrm{g}$ TOC with an average of $90 \mathrm{mg} \mathrm{HC} / \mathrm{g}$ TOC (Fig. 10a). The shales plot around the $\mathrm{HI}$ line at $100 \mathrm{mg} \mathrm{HC} / \mathrm{g}$ TOC (Fig. 10b).

Organic-rich carbonate facies are limited to those parts of the Minkinfjellet Formation with few evaporites and consist of mud- to wackestones interbedded with $0.5-1 \mathrm{~m}$ thick evaporites. The cumulative thickness of the organic-rich beds is approximately $8 \mathrm{~m}$, or $3 \%$ of 

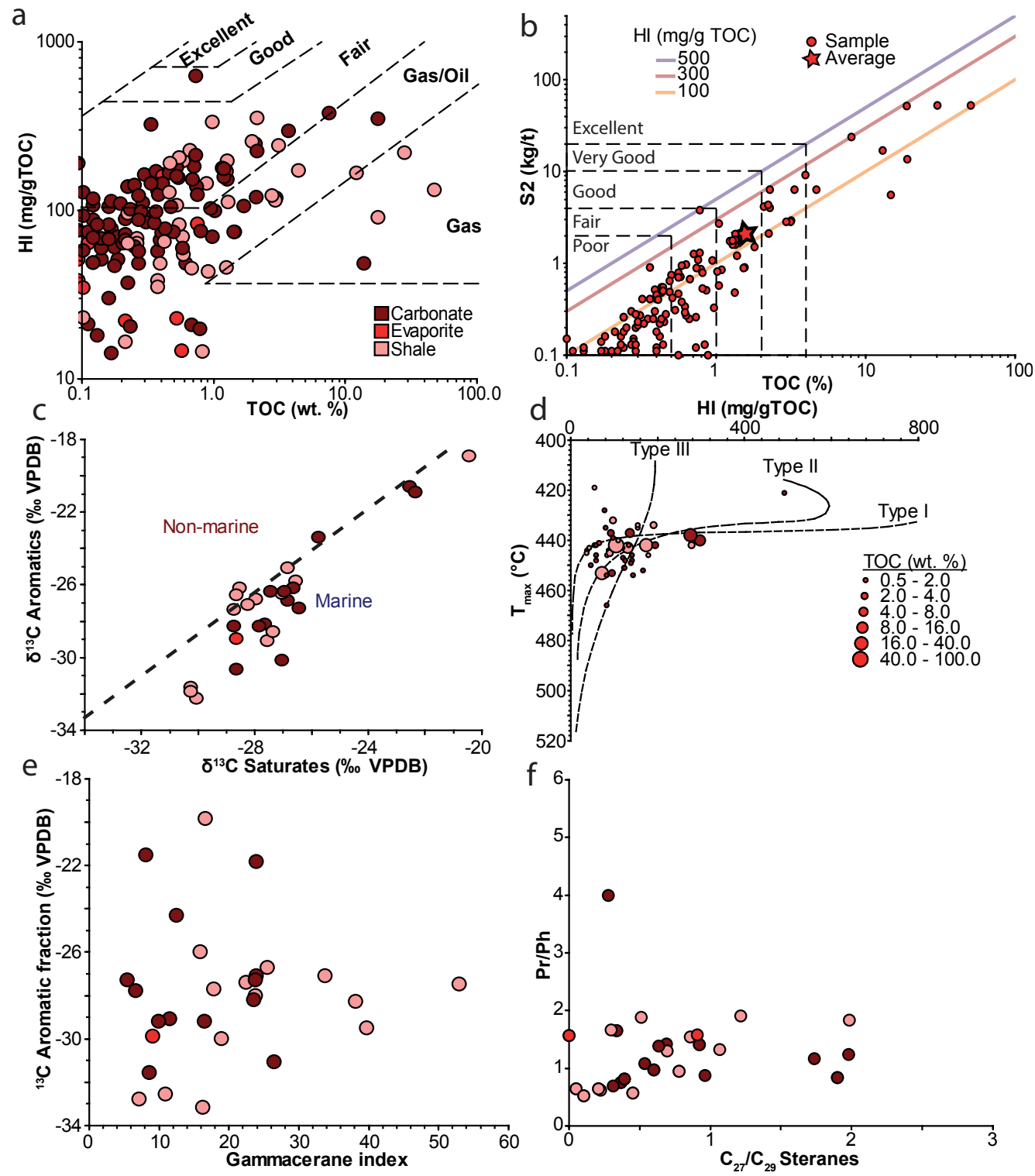

Fig. 10. Geochemical cross-plots of samples from the Ebbadalen and Minkinfjellet Formations.

(A) Hydrogen index ( $\mathrm{HI}$ ) versus total organic carbon (TOC); note that all the samples are mature and that the initial quality of the samples would have been higher. (B) Cross-plot of $S_{2}$ versus TOC for the sampled potential source rocks from Svalbard; averages for each formation are shown by the stars. (C) $\delta^{13} \mathrm{C}$ of the aromatic hydrocarbon fraction versus the saturated fraction in extracts from the samples. (D) Cross-plot of $\mathrm{HI}$ versus $\mathbf{T}_{\max }$ showing that most samples are within the oil window. $(E) \delta^{13} \mathrm{C}$ of the aromatic fraction plotted against the gammacerane index. (F) Cross-plot of $\mathrm{C}_{27} / \mathrm{C}_{29}$ sterane versus the pristane/phytane ratio.

the studied succession. TOC is between 1 and $50 \%$, with most samples containing less than $3 \mathrm{wt} . \%$, and $\mathrm{HI}$ values are between 40 and $500 \mathrm{mg} \mathrm{HC/g} \mathrm{TOC}$ with an average of $80 \mathrm{mg} \mathrm{HC} / \mathrm{g}$ TOC (Fig. 10a). The samples plot between the HI lines of 100 and $300 \mathrm{mg} \mathrm{HC} / \mathrm{g}$ TOC (Figs $10 \mathrm{~b}$ and $10 \mathrm{~d}$ ). The $n$-alkane distribution of the samples is unimodal, peaking at $n-\mathrm{C}_{17}$ (Fig. 12). In all three facies the $\mathrm{Pr} / \mathrm{Ph}$ ratio ranges from 0.5 to 2, with no evident systematic variations. Highly variable gammacerane indices are recorded for both carbonates and shales, ranging from 8 to 55 , whereas the evaporites are less variable, between 10 and 25 (Fig. $10 \mathrm{e})$. In plots of the $\delta^{13} \mathrm{C}$ of the saturated and aromatic hydrocarbon fractions (Fig. 10c), all the material falls in the area indicating marine dominated $\mathrm{OM}$. The $\mathrm{C}_{27}$ / $\mathrm{C}_{29}$ steranes ratios are between 0 and 2 (Fig. 10f) and the $\mathrm{C}_{35}$ hopane index varies between 0 and 0.5 (Fig. 11).

\section{Gipsdalen Group, Brucebyen Beds \\ (Gzelian-Asselian)}

The average TOC content of the analyzed carbonates varies laterally from 0.3 to $4.5 \mathrm{wt} . \%$ with an overall average of $2.1 \mathrm{wt} . \%$ TOC (Fig. 13a). Even larger stratigraphic variability is evident in most of the sampled sections, as exemplified in Fig. 5 where TOC ranges from 0.2 to $6 \mathrm{wt} . \%$. The material from 


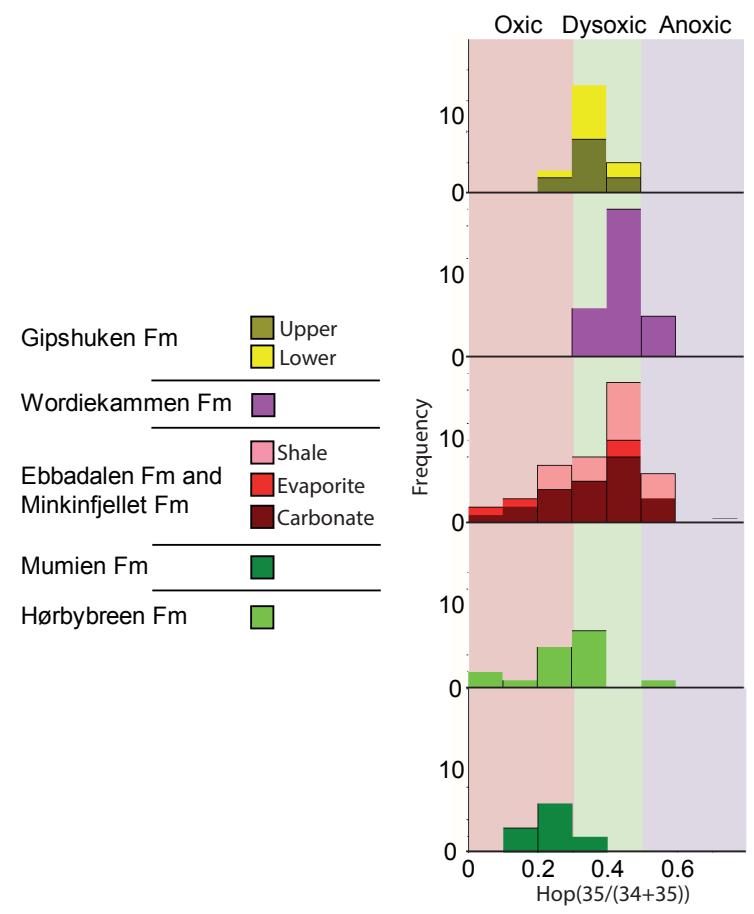

Fig. I I (above).Abundance of $C_{35}$ hopanes with indications of depositional environment (based on Peters and Moldowan, 1991). Note the wide range in the abundance of $\mathrm{C}_{35}$ hopanes in the Ebbadalen and Minkinfjellet Formations indicating deposition in a wide range of environments. See text for discussion.

FIg. I 2 (right). GC-FID chromatogram and GC-MS ion chromatograms of the saturated fraction, $\mathrm{m} / \mathrm{z}=191$ and $\mathrm{m} / \mathrm{z}=217$ fragmentograms of samples of the organic-rich marine carbonates of the Minkinfjellet Formation. Note "G" for gammacerane. See text for discussion.

Spitsbergen has $\mathrm{T}_{\max }$ values between 430 and $460{ }^{\circ} \mathrm{C}$, while the material from Bjørnøya has $\mathrm{T}_{\text {max }}$ around 500 ${ }^{\circ} \mathrm{C}$ (Fig. 13d). On a cross-plot of $\mathrm{S}_{2}$ versus TOC, the analyzed samples plot in two populations: one around the $300 \mathrm{HI}$ line, and the other around the $100 \mathrm{HI}$ line. Overall, the population plotting around the $\mathrm{HI}$ line at $300 \mathrm{mg} \mathrm{HC} / \mathrm{g}$ TOC contains $>1 \mathrm{wt} . \%$ TOC, while the other population contains $<1 \mathrm{wt} . \%$ TOC. The average $\mathrm{HI}$ is $162 \mathrm{mg} \mathrm{HC} / \mathrm{g} \mathrm{TOC}$, varying from 70 to $250 \mathrm{mg}$ $\mathrm{HC} / \mathrm{g}$ TOC (Fig. 13b).

In general, there is very little variability in the biomarker signatures. The $\mathrm{Pr} / \mathrm{Ph}$ ratios are between 1 and 2, the $\delta^{13} \mathrm{C}$ values of the saturated fraction ranges from -28 to $-31 \%$, with the $\delta^{13} \mathrm{C}$ values of the aromatic hydrocarbon fraction varying from -30 to $-34 \%$, and the gammacerane index shows values from 6 to 12 (Figs 13c, 13e, 14). The $\mathrm{C}_{27} / \mathrm{C}_{29}$ sterane ratio varies between 0.2 and 1.5 (Fig. 13f) and the $\mathrm{C}_{35}$ hopane
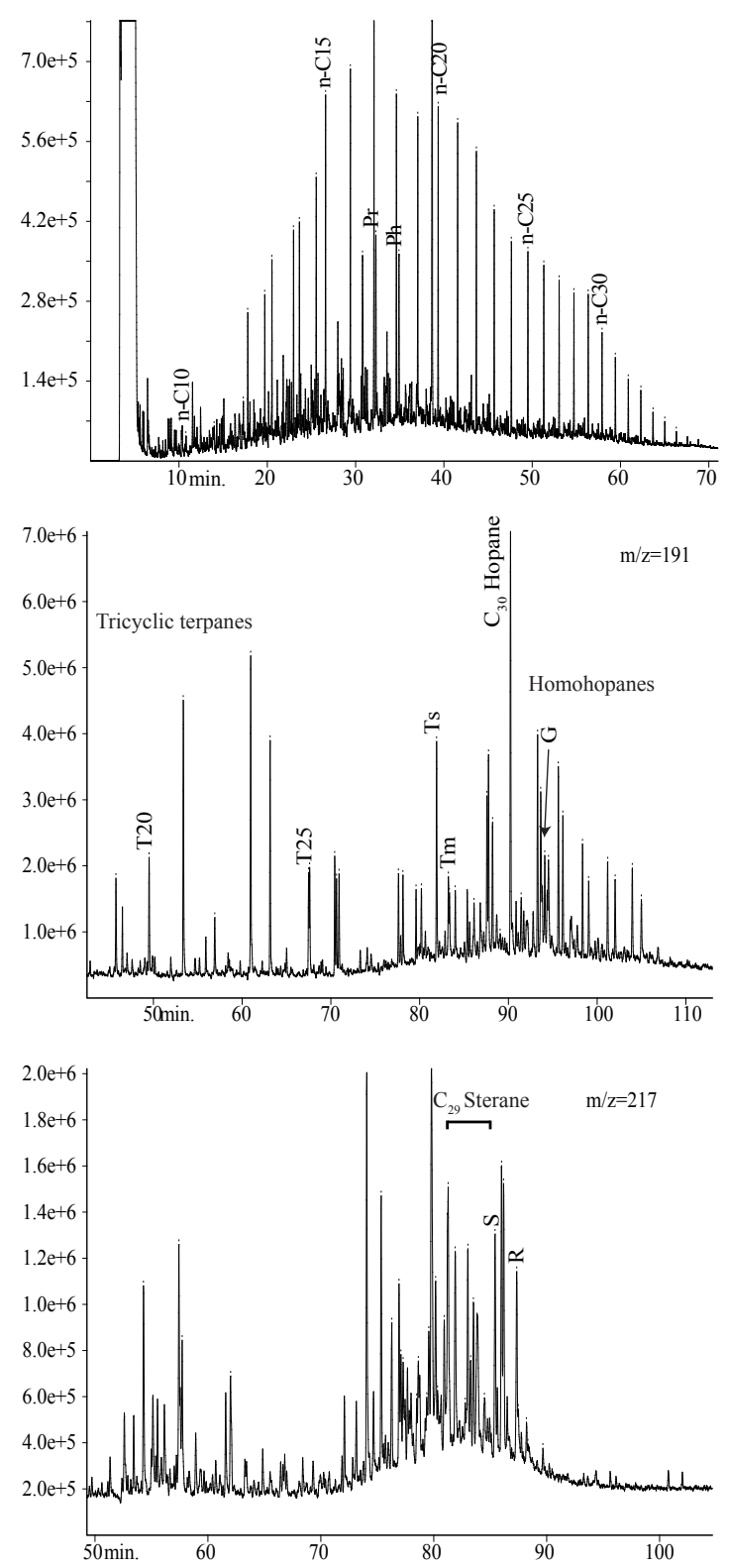

index between 0.3 and 0.5 (Fig. 11). Most samples from Spitsbergen have $\mathrm{C}_{27} / \mathrm{C}_{28}$ sterane ratios around 0.5 , while the samples from Bjørnøya have ratios around 0.8 and 1.2 (Fig. 13f).

\section{Gipsdalen Group, Gipshuken Formation (Sakmarian-Artinskian)}

Shales associated with evaporites contain 1-10 wt.\% TOC with an average of $4.2 \mathrm{wt} . \%$, and have $\mathrm{HI}$ values between 200 and $400 \mathrm{mg} \mathrm{HC} / \mathrm{g}$ TOC (Figs 15a and $15 \mathrm{~b}$ ). In a cross-plot of $\mathrm{S}_{2}$ versus TOC, they plot between the HI lines of 100 and $300 \mathrm{mg} \mathrm{HC} / \mathrm{g}$ TOC. The saturated hydrocarbon fraction of the samples ranges from $\delta^{13} \mathrm{C}-25$ to $-31 \%$, with that of the aromatic fraction showing values from -28 to $-32 \%$ (Fig. 15c). The $\mathrm{C}_{27} / \mathrm{C}_{29}$ sterane ratios ranges from 0.1 to 0.9 , the gammacerane index ranges from 8 and 32, and $\mathrm{Pr} / \mathrm{Ph}$ ratio is around 1.5 (Figs 15d, 15f). 

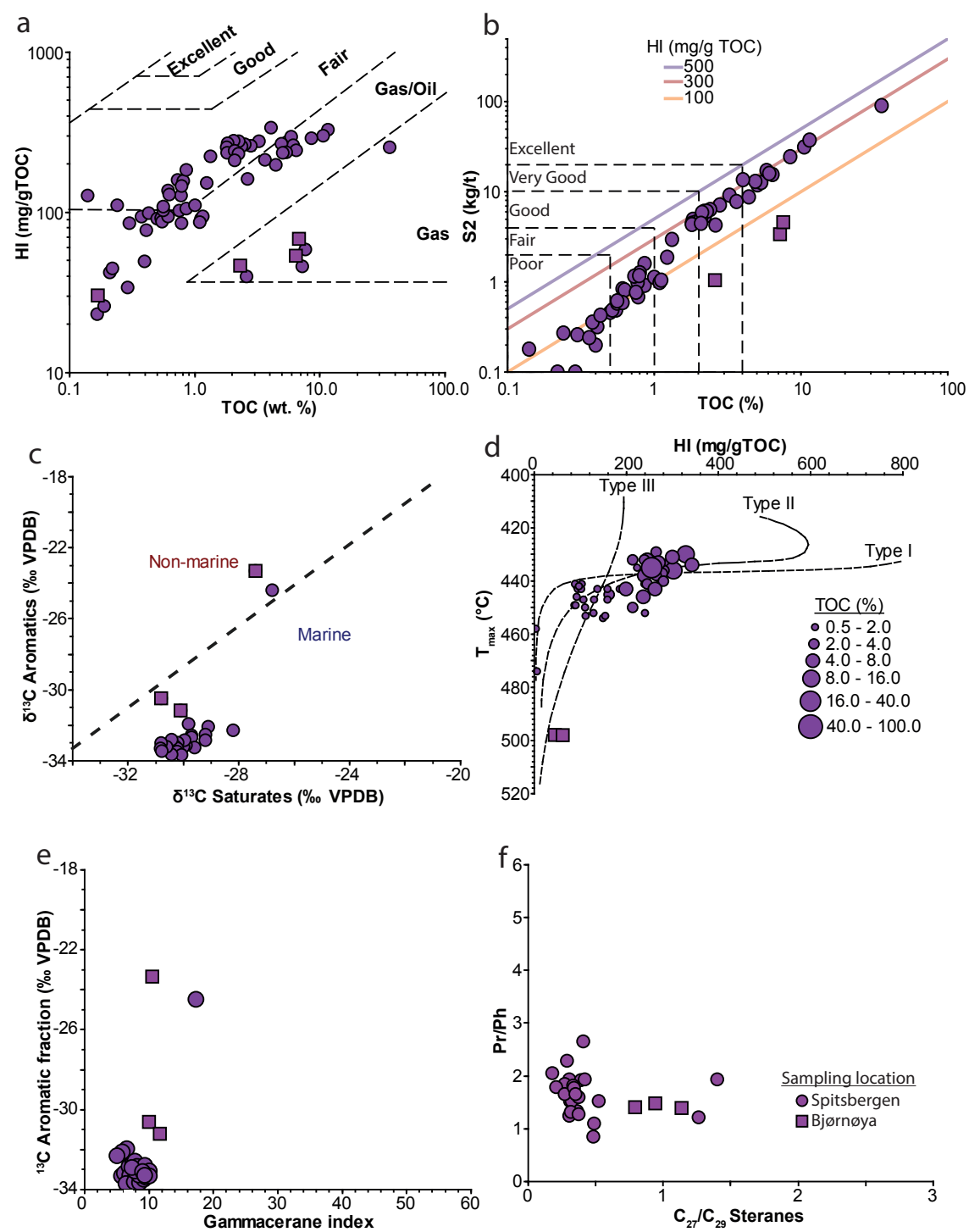

Fig. 13. Geochemical plots of samples from the Wordiekammen Formation. (A) Hydrogen index (HI) versus total organic carbon (TOC); note that all the samples are mature and that the initial quality of the samples would have been higher. (B) Cross-plot of $S_{2}$ versus TOC for sampled potential source rocks in Svalbard; averages for each formation are shown by stars. (C) $\delta^{13} \mathbf{C}$ of the aromatic versus the saturated fraction extracted from the samples. (D) $\mathrm{HI}$ versus $\mathrm{T}_{\max }$ showing that most samples are within the oil window. (E) $\delta^{13} \mathbf{C}$ of the aromatic fraction plotted against the gammacerane index. (F) Cross-plot of $\mathbf{C}_{27} / \mathbf{C}_{29}$ sterane versus pristane / phytane ratio.

The shales associated with marine carbonates contain $1-90$ wt. $\%$ TOC with an average of $10 \mathrm{wt} . \%$, and $\mathrm{HI}$ is in the range from 100 to $350 \mathrm{mg} \mathrm{HC/g}$ TOC (Figs 15a and 15b). On a cross-plot of $\mathrm{S}_{2}$ versus TOC, they plot around the $\mathrm{HI}$ line at $300 \mathrm{mg} \mathrm{HC} / \mathrm{g}$ TOC (Fig. 15c). The hydrocarbons are dominated by short-length $n$-alkanes, with a unimodal distribution peaking at $n-\mathrm{C}_{14}$ (Fig. 16). The saturated hydrocarbon fraction of the material ranges from -25 to $-30 \% \delta^{13} \mathrm{C}$, and the aromatic hydrocarbon fraction from -28 to $-32 \%$ (Fig. $15 \mathrm{c})$. The $\mathrm{C}_{27} / \mathrm{C}_{29}$ sterane ratios vary between 0.2 and 1.25 , the gammacerane index varies from 9 and 17 , and $\mathrm{Pr} / \mathrm{Ph}$ is around 1.5 (Figs 15d, 15f). Mo concentrations are high (17-165 ppm).

\section{DISCUSSION}

The present data-set provides a comprehensive characterization of Upper Palaeozoic organic-rich sediments in Svalbard and is summarized in Fig. 17. The analyzed material from Spitsbergen shows evidence of maturation corresponding to the oil window, with a normal distribution of $\mathrm{T}_{\text {max }}$ values around $440{ }^{\circ} \mathrm{C}$ (Fig. 18). Thus all the analyzed organic-rich intervals have produced petroleum and accordingly have lower $\mathrm{S}_{1}$ and $\mathrm{S}_{2}$ values than samples from offshore regions. This is evident when comparing material from the Billefjorden Group from Svalbard with material of similar source type from the Barents Shelf (Fig. 19). 


\section{Billefjorden Group}

The combined sedimentological and geochemical data-set indicates that both lateral and stratigraphic variations in source potential and quality of the fluviolacustrine sediments in the Billefjorden Group are to be expected. The relatively high $\mathrm{Pr} / \mathrm{Ph}$ ratios in the samples from Birger Johnsonfjellet indicate oxidizing conditions, at least locally and a more terrestrial input (c.f Peters et al., 2005) (Fig. 7c). The overall low gammacerane index indicates limited stratification within the water column (Fig. 7e). The low $\mathrm{C}_{27} / \mathrm{C}_{29}$ sterane ratio (Fig. 7f), the lack of $\mathrm{C}_{30}$ steranes (Fig. 9) and the low $\mathrm{C}_{35}$ hopane index (Fig. 11) are consistent with deposition in a mainly oxic fluvio-lacustrine environment.

The Hørbyebreen Formation shows larger variations of TOC and HI values than the overlying Mumien Formation in accordance with its suggested floodplain origin (Fig. 3; cf. Gjelberg and Steel, 1981). High TOC is recorded in coals deposited in peat swamps, and in lacustrine shales dominated by the colonial alga Botryococcus brauni which have higher HI values. This difference in depositional environment is reflected in the $\mathrm{S}_{2}-\mathrm{HI}$ cross-plot where the coaly facies follows the $\mathrm{HI}$ line at $100 \mathrm{mg} \mathrm{HC} / \mathrm{g} \mathrm{TOC}$, and the lacustrine facies the $\mathrm{HI}$ line at $300 \mathrm{mg} \mathrm{HC/g} \mathrm{TOC} \mathrm{(Fig.} \mathrm{7b);} \mathrm{this}$ most likely relates to facies-controlled differences in the ratio of lacustrine algal material relative to higher plant material. The HI values are highest in the Mumien Formation in accordance with suggested deposition in lacustrine-dominated environments (e.g. Abdullah et al., 1988). However, this shift in depositional environment is not detected in the biomarker data which suggests that the overall composition of the organic matter did not change over time (Fig. 7d).

The data-set indicates that lacustrine intervals in the Hørbybreen and Mumien Formations have the potential to produce both oil and gas. Pyrolysis-GC of organic material from the Birger Johnsonfjellet indicates an average present-day gas-to-oil ratio of 0.2 , and suggest that both sedimentary successions are primarily gas/ oil prone. The gas to oil prone nature of parts of the Lower Carboniferous shales and coals is supported by the composition of oil from a shallow onshore borehole in the inner part of Billefjorden drilled by Trust Articgul in 1992. Analyses from this borehole gave an $n$-alkane signature indicating sourcing from a terrigenous source rock like the Billefjorden Group (Verba, 2007). Carboniferous sediments with source rock potential have been described from offshore wells 7120/2-1, 7128/6-1 and 7281/4-1 (van Koeverden et al., 2010). In these wells, the organic material is of terrigenous origin and resembles the mixed humic and limnic material described from Birger Johnsonfjellet. It is therefore likely that organic-rich fluvio-lacustrine deposits are present over large areas of the SW Barents
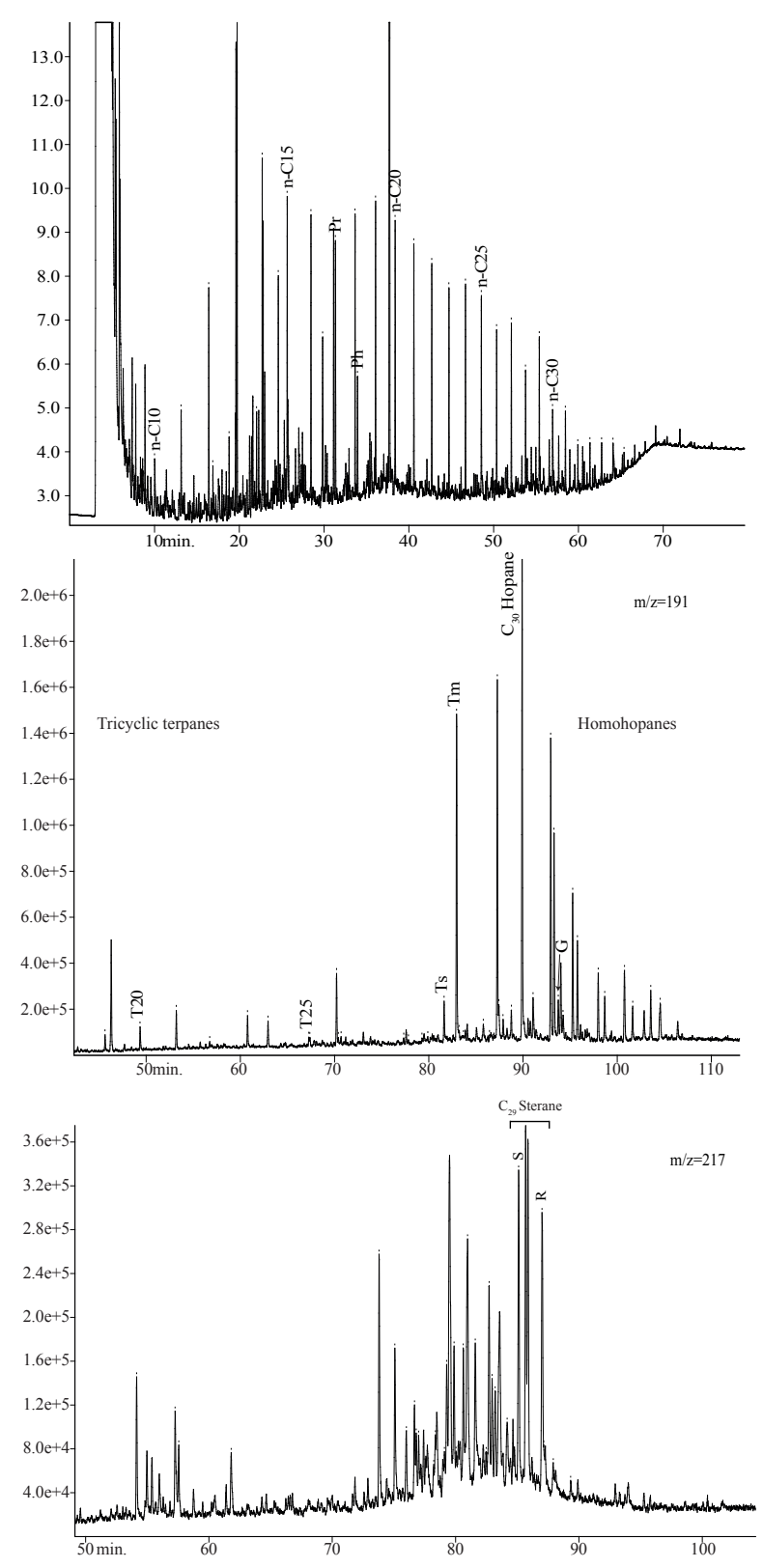

Fig. 14. GC-FID chromatogram and GC-MS ion chromatograms $\mathrm{m} / \mathrm{z}=191$ and $\mathrm{m} / \mathrm{z}=217$ fragmentograms of samples of the Wordiekammen Formation.

Sea, providing a source for both oil and gas in areas where it is buried to sufficient depths. Eastwards, the Lower Carboniferous succession passes into marine sediments in the Russian part of the Barents Shelf with marine incursions reported to reach the easternmost Norwegian Finnmark Platform (7029/03-U-01) during the Visean (e.g. Bugge et al., 1995).

Thicker successions of Carboniferous lacustrine organic-rich shales have been described from localized lows along the down-dip margin of rotated fault blocks in the rift basins in east Greenland (Stemmerik et al., 1990; Christiansen et al., 1990). The presence of similar facies along fault blocks on the Barents Shelf may add to the Lower Carboniferous source potential. 

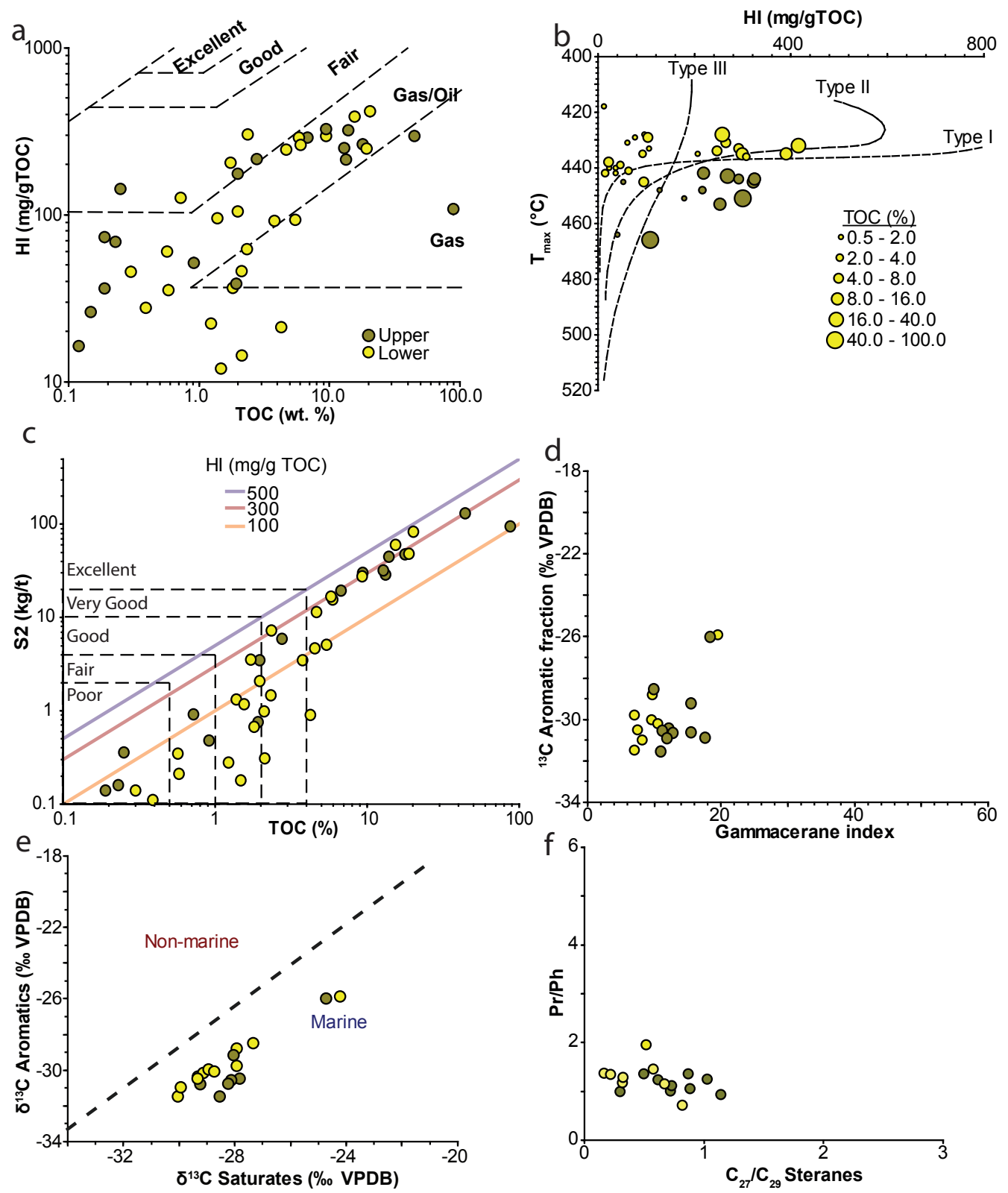

Fig. I5. Geochemical cross-plots of samples from the Gipshuken Formation. (A) Hydrogen index (HI) versus total organic carbon (TOC); note that all the samples are mature and that the initial quality of the samples would have been higher. (B) Cross-plot of $S_{2}$ versus TOC for sampled potential source rocks in Svalbard; averages for each formation are shown by stars. (C) $\delta^{13} \mathbf{C}$ of the aromatics versus the saturated fraction extracted from the samples. (D) $\mathrm{HI}$ versus $\mathrm{T}_{\max }$ showing that most samples are within the oil window. (E) $\delta^{13} \mathrm{C}$ of the aromatic fraction plotted against the gammacerane index. (F) Cross-plot of $\mathrm{C}_{27} / \mathrm{C}_{29}$ sterane versus pristane / phytane ratio.

However, no such deposits have been described from Svalbard, and their preservation potential is also a risk since the tops of the east Greenland successions are frequently eroded by coarse-grained alluvial and fluvial conglomerates and sandstones (Stemmerik et al., 1990).

\section{Gipsdalen Group}

The fine-grained, organic-rich facies in the Gipsdalen Group were deposited in a range of marine shelf environments, reflecting shifts in both tectonic setting and climate over time.
The geochemical data-set derived from the evaporitic Trikolorfjellet and Minkinfjellet synrift succession indicates that all the analyzed samples are dominated by marine OM possibly with a slightly higher input of terrigenous organic material in the shales and overall better preservation of $\mathrm{OM}$ in the carbonate facies, as indicated by their different distributions relative to the $\mathrm{HI}$ trend lines. The mix of marine and terrigenous $\mathrm{OM}$ is also evident from the high variability in the $\mathrm{C}_{27} / \mathrm{C}_{29}$ steranes ratios and $\mathrm{C}_{35}$ hopane index (Figs 9 and 10f). The relatively high gammacerane index of some shales and carbonates 
Fig. 16. GC-FID chromatogram and GCMS $\mathrm{m} / \mathrm{z}=|9|$ and $\mathrm{m} / \mathrm{z}=217$ fragmentograms, representative of the marine shales in the Gipshuken Formation at Nøisdalen (G4 in Fig. I).
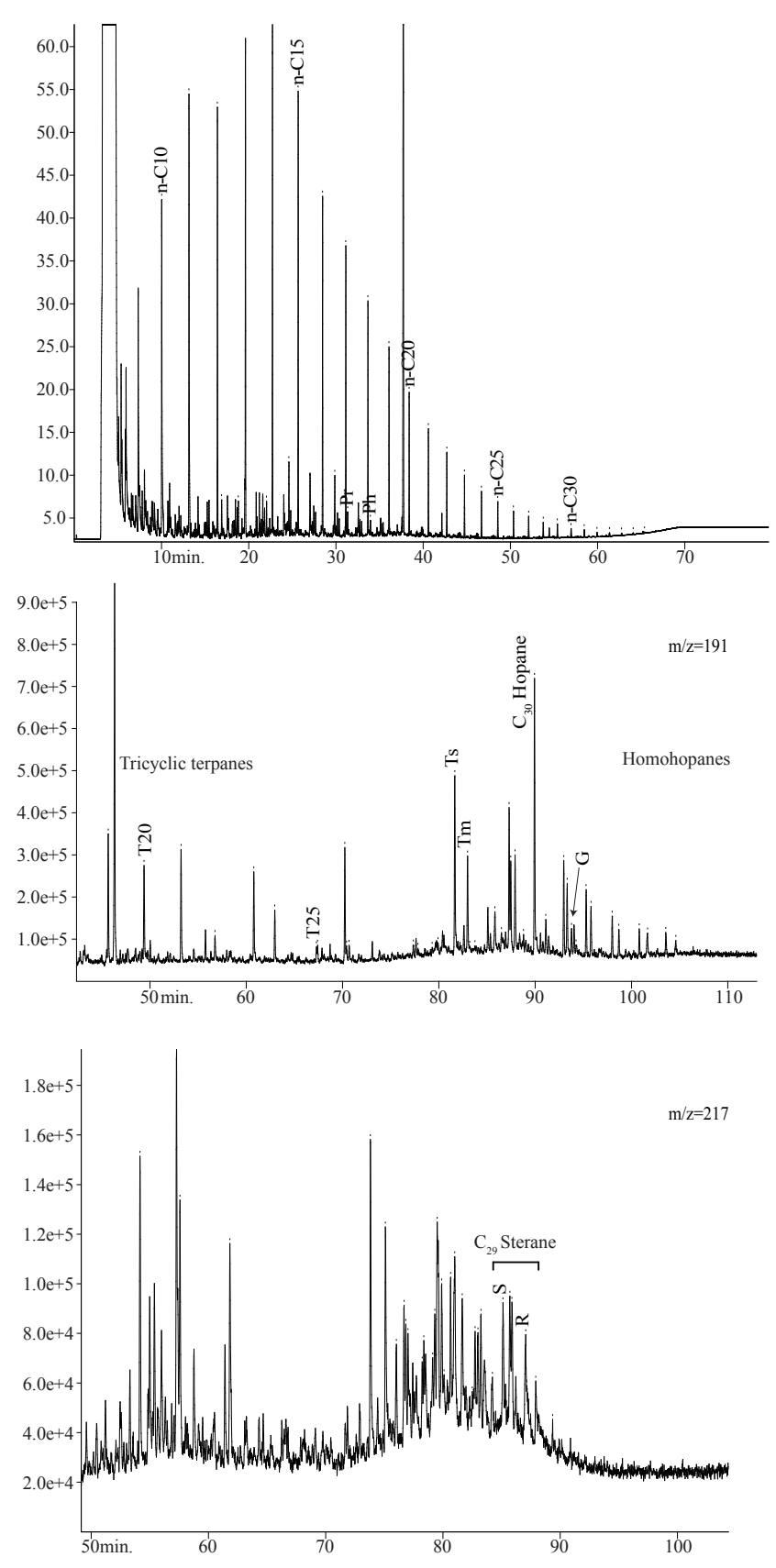

Fig. 17. Summary diagram for organic-rich deposits in Svalbard, with depositional environments, net source thicknesses, TOC ranges with average indicated, and Hydrogen Index with average indicated. 


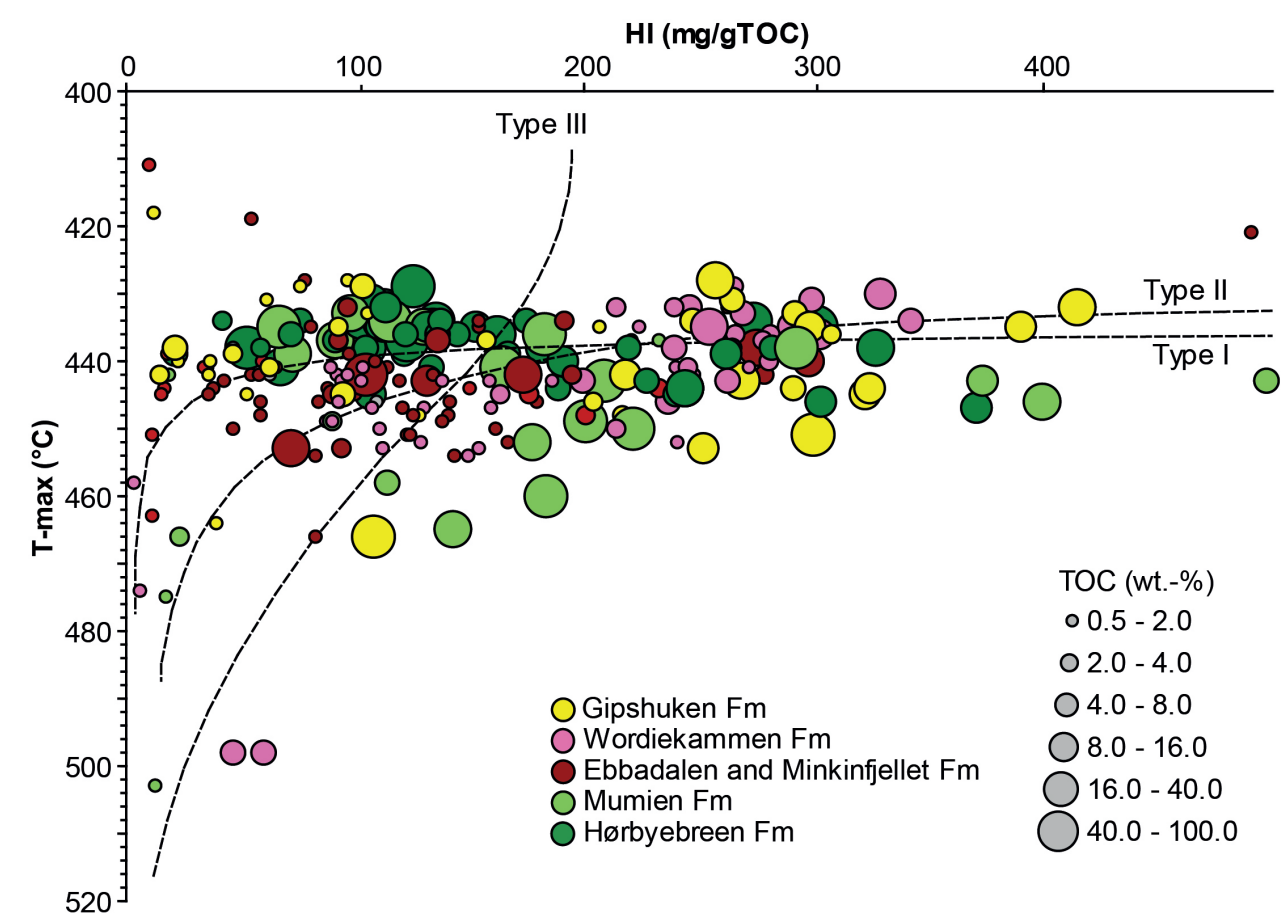

Fig. 18. HI versus $T_{\max }$ cross-plot for all the samples collected in Svalbard; note that the samples with $\mathrm{T}_{\max }$ of about $500^{\circ} \mathrm{C}$ were collected on Bjørnøya, approximately $450 \mathrm{~km}$ to the south of the other sample locations. Bjørnøya is considered to have been uplifted by about $4 \mathrm{~km}$ (Nyland et al., 1992). Most of the samples from Spitsbergen plot within the oil-window and on the trajectory of Type I or II kerogen.

suggests temporary stratification of the water column (Peters et al., 2015). Pyrolysis GC chromatograms of the carbonate samples show an average gas-to-oil ratio of 0.2 , indicating that they are primarily oil prone.

The data-set thus indicates that marine intervals in the lower part of the Gipsdalen Group on Spitsbergen have the potential to produce petroleum. Deposition took place in relatively narrow syn-rift basins during a regional Serpukhovian-Bashkirian rift event, and similar basins are recognized seismically across the western Barents Shelf where the time-equivalent synrift fill is included in the Ugle and Falk Formations (e.g. Larssen et al., 2005). The data from Svalbard suggest the potential presence of organic-rich intervals with source potential at the base of the Gipsdalen Group across wide areas on the SW Barents Shelf. In the uplifted parts of Spitsbergen, organic-rich facies with source rock potential correspond to $1-3 \%(8 \mathrm{~m})$ of the succession.

The presence of organic-rich intervals in the thick carbonate platform successions of the upper Gipsdalen Group (the Ørn Formation equivalent) is limited to the Brucebyen Beds, and apparently deposition occurred during a major transgression in the latest Carboniferous to earliest Permian (Nilsson, 1993). The $\mathrm{Pr} / \mathrm{Ph}$ and $\mathrm{C}_{27} / \mathrm{C}_{29}$ sterane ratio, and the cross-plot of $\delta^{13} \mathrm{C}$ of the saturated and aromatic hydrocarbon fractions, all indicate that the organic matter is of marine origin, in accordance with the open-marine setting proposed by Ahlborn an Stemmerik (2015), see Figs 13c, 13e, 13 f. This contrasts with earlier studies where the material is described as terrigenous based mainly on kerogen type (e.g. Hanken and Nielsen, 2015). Identification of organic material based on optically determined kerogen type can be misleading with respect to generated petroleum, especially when working with mature samples (Peters et al., 2005).

The $\delta^{13} \mathrm{C}$ of the aromatic and saturated fractions, gammacerane as well as the $\mathrm{Pr} / \mathrm{Ph}$, the $\mathrm{C}_{27} / \mathrm{C}_{29}$ sterane ratios and $\mathrm{C}_{35}$ hopane index are uniform, indicating that the composition of the organic matter and the palaeodepositional environment was relatively uniform across the platform. The observed variability in TOC and $\mathrm{HI}$ probably reflects variable oxygenation of the water column across the platform (e.g. Hughes et al., 1995) due to a combination of palaeo-bathymetry and high frequency sea-level fluctuations (e.g. Ahlborn and Stemmerik, 2015) i.e. due to the Gondwanland glaciations. Organic-rich carbonates of similar age also occur at Bjørnøya, some $450 \mathrm{~km}$ to the south (Stemmerik et al., 1994), suggesting that this facies is semi-regionally widespread.

The data-set thus indicates that a stratigraphically restricted, but laterally widespread interval in the Gipsdalen carbonate platform succession has the potential to produce petroleum. However, organic-rich carbonates have so far not been encountered in the time-equivalent Ørn Formation on the Barents Shelf (Stemmerik and Worsley, 2005), and it is therefore difficult to judge its regional significance. Pyrolysis GC of the samples indicated an average gas-to-oil ratio of 0.13 , indicating that immature equivalents are 
Fig. 19. Cross-plot of $\mathrm{S}_{2}$ against TOC for samples from the Billefjorden Group in Svalbard and from well 7/28/6- I and 728I/4- I in the South Barents Sea.The dashed line indicates an $\mathrm{HI}$ value of $300 \mathrm{mg} \mathrm{HC} / \mathrm{g}$ TOC.

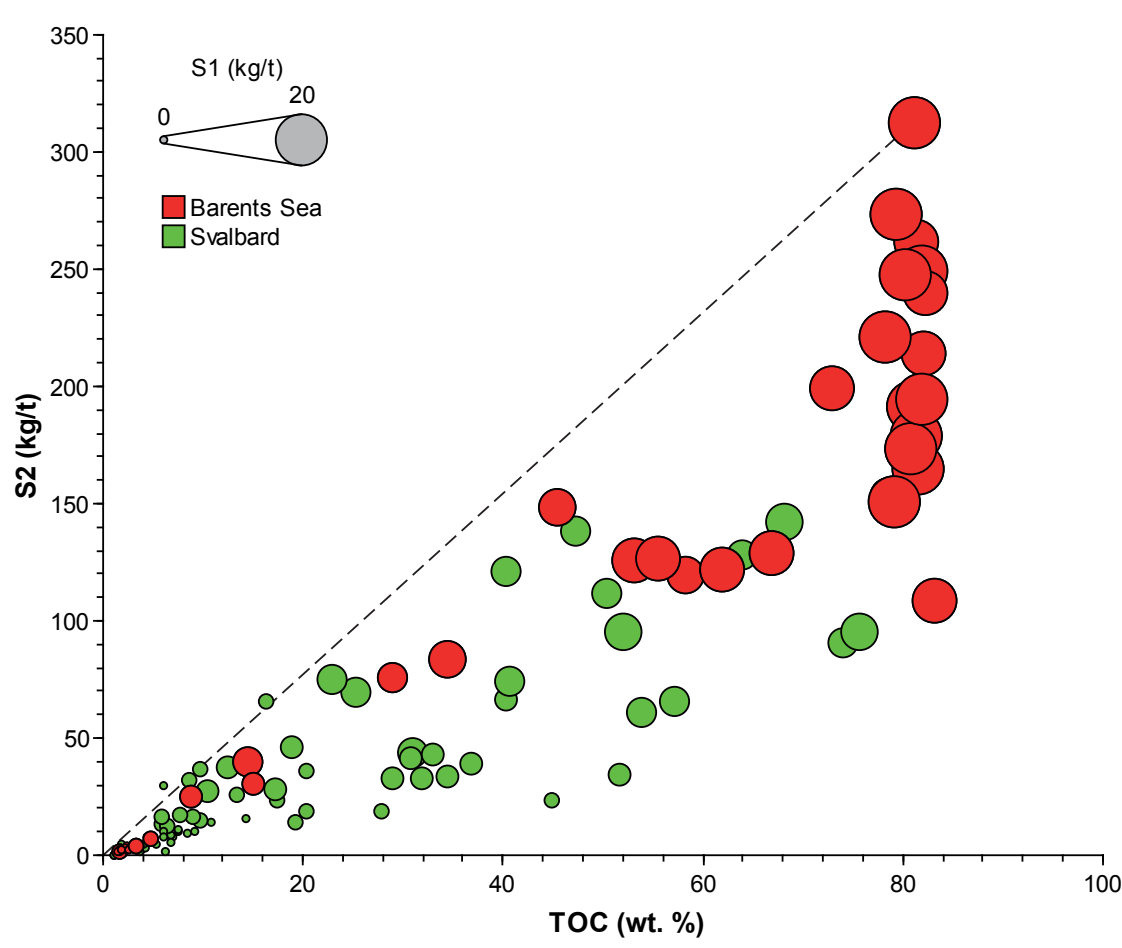

likely to be oil prone. It is noteworthy in this respect that Matapour and Karlsen (2017) and Matapour et al. (2018), studying bitumen and oil at the Alta discovery on the Loppa High, recorded a marine Palaeozoic agespecific biomarker petroleum signature, suggesting that at least some of the petroleum at Alta/Gohta is of a Palaeozoic origin.

The geochemical data-set from the lower evaporitic part of the Gipshuken Formation shows many similarities with the data-set obtained from the Trikolorfjellet-Minkinfjellet facies. This indicates that organic-rich shales dominated by marine OM were deposited in proximal evaporitic settings into the Early Permian, suggesting a potentially wider stratigraphic range for these evaporite-dominated organic-rich facies in the offshore areas, e.g. associated with the Fafner unit east of the Loppa High (Ahlborn et al., 2014).

The geochemical data-set derived from the shales associated with marine carbonates in the upper Gipshuken Formation, including the stable carbon isotopes, $\mathrm{Pr} / \mathrm{Ph}$ and $\mathrm{C}_{27} / \mathrm{C}_{29}$ sterane ratios, indicate a marine origin of the $\mathrm{OM}$ in this part of the succession. This contrasts with the occasional presence of small woody fragments in the shales, indicating that part of the $\mathrm{OM}$ is of terrigenous origin; these woody fragments are possibly erosional products brought into the basin. The high Mo concentrations and the occasional preservation of lamination reflect deposition under anoxic conditions, and interbedding with bioturbated biogenic carbonate pack- and wackestones suggests rapidly fluctuating oxygen levels, possible in a setting close to the storm wave base (Tone Sorento Tågholt, pers. comm., 2018). Thus, anoxic conditions existed at least locally across the Barents Shelf carbonate platform during the Early Permian, permitting thin organic-rich shales to be deposited. Pyrolysis GC results of the marine shale samples gave an average gas-to-oil ratio of 0.2 , indicating that they are primarily oil-prone in the uplifted areas of Spitsbergen.

The organic-rich marine shales in the upper Gipshuken Formation have no reported offshore equivalents in the Bjarmeland Group and their importance is difficult to access. They document that organic material accumulated under anoxic conditions in cool-water, outer ramp settings, and it is possible that upwelling began to influence the shelf during Bjarmeland times.

\section{Source-related biomarkers}

The source rocks analyzed in this study represent a broad range of depositional environments and this is reflected in the biomarker signatures of the organic matter and the related oils. The different depositional environments in Svalbard can be distinguished using the gammacerane index, $\delta^{13} \mathrm{C}$ values of the aromatic fraction, and the $\mathrm{C}_{27} / \mathrm{C}_{29}$ sterane plus the $\mathrm{Pr} / \mathrm{Ph}$ ratios (Table 2).

The Billefjorden Group is characterized by a combination of relatively heavy $\delta^{13} \mathrm{C}$ values, low gammacerane index and high $\mathrm{Pr} / \mathrm{Ph}$ ratios. Hydrocarbon signatures from the Carboniferous Minkinfjellet and Ebbadalen Formations are difficult to distinguish from those of the Lower Permian Gipshuken Formation, which is not surprising since the organic-rich sediments were deposited in comparable, evaporitic-dominated environments. The Ebbadalen, Minkinfjellet and Gipshuken Formations, however, are easy to distinguish from the Billefjorden Group 
Table 2. Characteristic parameters for distinguishing the analyzed source rocks.

\begin{tabular}{cccc}
\hline Group/Formation & $\delta^{13} \mathrm{C}$ & Gammacerane index & $\mathrm{Pr} / \mathrm{Ph}$ \\
\hline Gipshuken Formation & $-32--28$ & $7-20$ & $0.7-1.5$ \\
Wordiekammen Formation & $-33--32$ & $5-10$ & $1-2.5$ \\
$\begin{array}{c}\text { Ebbadalen Formation and } \\
\text { Minkinfjellet Formation }\end{array}$ & $-32--26$ & $7-40$ & $0.5-2$ \\
Billefjorden Group & $-27--24$ & $2-6$ & $2-5.5$ \\
\hline
\end{tabular}

since the associated $\delta^{13} \mathrm{C}$ of the aromatic fraction is lighter, the gammacerane index higher, and the $\mathrm{Pr} / \mathrm{Ph}$ ratio lower than in the Billefjorden Group (Table 2). The Brucebyen Beds can be distinguished from the Billefjorden Group based on the $\delta^{13} \mathrm{C}$ values of the aromatic hydrocarbon fractions.

\section{CONCLUSIONS}

Geochemical data from organic-rich shales and carbonates of Late Palaeozoic age outcropping in Svalbard suggests that:

(i) The fluvio-lacustrine intervals in the Mumien and Hørbyebreen Formations (Billefjorden Group) are active oil-generating source rocks in Spitsbergen. The organic material is mainly kerogen Type II, but there are indications that Type I kerogens occur in areas where lacustrine deposits are present. The TOC values range between 1 and 75 wt.\%, and the organic-rich section has a cumulative thickness of more than 100 $\mathrm{m}$. It can be distinguished from other Upper Palaeozoic source rocks in Svalbard by its high $\mathrm{Pr} / \mathrm{Ph}$ ratios, heavy $\delta^{13} \mathrm{C}$ signatures and low gammacerane ratio.

(ii) The evaporitic Trikolorfjellet Member and the Minkinfjellet Formation in the lower part of the Gipsdalen Group have three potential source rock facies; shales, shales interbedded in evaporites, and organic-rich carbonates. The source rock potential is in Svalbard limited due to moderate TOC contents. The facies with the highest potential is the organicrich carbonates with TOC up to $20 \mathrm{wt} . \%$, which have a cumulative thickness of $8 \mathrm{~m}$ and which are confined to the deepest part of the onshore rift basins.

(iii) In the Ørn Formation -equivalent Wordiekammen Formation, a widespread organicrich unit, 2-10 m thick, contains 1-10 wt.\% TOC, and pyrolysis-gas chromatography data suggest that it is oil prone. The semi-regional distribution of the Brucebyen Beds along the western margin of the Barents Shelf suggests that it is a potential source rock, at least in this part of the shelf.

(iv) The presence of organic-rich facies in the Gipshuken Formation extends the stratigraphic range of potential source rocks into sections equivalent to the offshore Bjarmeland Group, particularly the presence of organic-rich marine shales with an average of 10 wt.\% TOC and hydrogen index values of between 200 and $400 \mathrm{mg} \mathrm{HC} / \mathrm{g}$ TOC. This facies attains very limited thicknesses onshore Svalbard, but may be thicker in more distal offshore settings. However, at present its stratigraphic and geographical ranges are unknown.

(v) The Kapp Starostin Formation (Tempelfjorden Group) has no documented source rock potential in Spitsbergen.

(vi) It is likely that petroleum in the Barents Shelf can potentially be tied to organic-rich facies at formation level based on the gammacerane index, the $\delta^{13} \mathrm{C}$ value of the aromatic fraction, and/or the $\mathrm{Pr} / \mathrm{Ph}$ ratio.

(vii) Carboniferous strata, where present, are likely to contain an effective source rock on the Barents Shelf, especially in the eastern part where burial has not completely transformed the organic matter into (presumably) dry gas.

(viii) For the Permian succession, the potential to supply a working petroleum system is more uncertain since intervals of good to excellent source rock are thinner and less predictable. The organic-rich intervals in the Gipshuken Formation are probably the best candidates; also, primary migration may occur within the carbonate facies.

(ix) Offshore mapping, preferably with the assessment of source rock quality based on seismic attributes in combination with depositional models, will be a key to the further evaluation of the Palaeozoic petroleum systems on the Barents Shelf.

\section{ACKNOWLEDGEMENTS}

The authors thank Aker BP (former Det Norske); Alexander Hartwig (Aker BP) for valuable discussions; APT (Applied PetroleumTechnology AS) for the analyses;Tais W. Dahl for the introduction to trace element analysis and XRF supervision; Ingeborg Verstad, Ann-Christin Holme, Line Bruun Nicolaisen, Troels Frøhlke Nielsen, Aleksandra Smyrak-Sikora, Tone Sorento Tågholt; Erik P. Johannessen for indispensable help during fieldwork, data collection and preliminary discussions; and Dag Arild Karlsen for constructive review. 


\section{REFERENCES}

ABAY, T. B., KARLSEN, D. A., LERCH, B., OLAUSSEN, S., PEDERSEN, J. H. and BACKER-OWE, K., 2017. Migrated petroleum in outcropping Mesozoic sedimentary rocks in Spitsbergen: Organic geochemical characterization and implications for regional exploration. Journal of Petroleum Geology, 40, 5-36.

ABDULLAH,W. H., MURCHISON, D., JONES, J. M., TELNAES, $\mathrm{N}$. and GJELBERG, J., 1988. Lower Carboniferous coal deposition environments on Svalbard, Svalbard. Organic Geochemistry, 13, 953-964.

AHLBORN, M., and STEMMERIK, L., 20I5. Depositional evolution of the Upper Carboniferous - Lower Permian Wordiekammen carbonate platform , Nordfjorden High , central Svalbard,Arctic Norway. Norwegian Journal of Geology, 95, $91-126$.

AHLBORN, M., STEMMERIK, L. and KALST Ø, T.K. 20I4. 3D seismic analysis of karstified interbedded carbonates and evaporites, Lower Permian Gipsdalen Group, Loppa High, southwestern Barents Sea. Marine and Petroleum Geology, 56, I6-33.

BLOMEIER, D., DUSTIRA, A., FORKE, H. and SCHEIBNER, C., 20II. Environmental change in the Early Permian of NE Svalbard: From a warm-water carbonate platform (Gipshuken Formation) to a temperate, mixed siliciclasticcarbonate ramp (Kapp Starostin Formation). Facies, 57, 493-523.

BRAATHEN, A., B/ELUM, K., MAHER JR., H. and BUCKLEY, S. J., 20I I. Influence of extensional fault growth and folding on sediment transport and depozone characteristics in an evaporite-dominated rift-basin system; the Carboniferous Billefjorden Trough, Svalbard. Norwegian Journal of Geology, 91, I37-160.

BRAATHEN,A., BAELUM, K., DAHL,T., ELVEBAKK,H., HANSEN, F., HANSSEN, T.H., JOCHMANN, M., JOHANSEN, T.A., JOHNSEN, H., LARSEN, L., MERTES, J., MøRK, A., MøRK, M. B., NEMEC,W.J., OLAUSSEN, S., RØED, K.,TITLESTAD, G.O., TVERANGER, J. and OYE, V., 20I2. Longyearbyen CO2 lab of Svalbard, Norway - first assessment of the sedimentary succession for CO2 storage. Norwegian Journal of Geology, 92, 353-376.

BUSTIN, R., CAMERON, A., GRIEVE, D. and KALKREUTH, W.D., 1989. Coal Petrology - Its principles, methods and applications. Geological Association of Canada, Short Course Notes, 273 pp.

CHRISTIANSEN, F.G., OLSEN, H.,PIASECKI,S. and STEMMERIK, L., 1990. Organic geochemistry of Upper Palaeozoic lacustrine shales in the East Greenland basin. Organic Geochemistry, 16, 287-294.

DALLMANN,W., 1999. Lithostratigraphic Lexicon of Svalbard. Lørenskog, Norsk Polarinstitut, 320 pp.

GJELBERG, J. and STEEL, R. J., I98I. An outline of LowerMiddle Carboniferous sedimentation on Svalbard: Effects of tectonic, climatic and sea level changes in rift basin sequences. Geology of the North Atlantic Borderlands, 7, 543-56I.

GJELBERG J., 1984. Early-Middle Carboniferous sedimentation on Svalbard. Unpublished Dr. scient.Thesis, Univ. of Bergen, Norway, 336 pp.

HUGHES, W. B., HOLBA, A. G. and DZOU, L. I., 1995. The ratios of dibenzothiophene to phenanthrene and pristane to phytane as indicators of depositional environment and lithology of petroleum source rocks. Geochimica et Cosmochimica Acta, 59, 358I-3598.

HÜNEKE, H.,JOACHIMSKI, M., BUGGISCH,W. and LLITZNER, H., 200I. Marine Carbonate Facies in Response to Climate and Nutrient Level:The Upper Carboniferous and Permian of Central Svalbard (Svalbard). Facies, 45, 93-I36.

JAFARIAN, E., KLEIPOOL, L. M., SCHEIBNER, C., BLOMEIER, D.
P. G. and REIJMER, J. J. G., 2017.Variations in petrophysical properties of Upper Palaeozoic mixed carbonate and noncarbonate deposits, Spitsbergen, Svalbard archipelago. Journal of Petroleum Geology, 40, 59-83.

van KOEVERDEN,J.H. and KARLSEN, D.A., 20I I.Carboniferous non-marine source rocks from Svalbard and Bjørnøya: comparison with the Western Arctic. Journal of Petroleum Geology, 34, 53-66.

van KOEVERDEN, J. H., KARLSEN, D. A., SCHWARK, L. and CHPITSGLOUZ,A., 2010. Oil-prone Lower Carboniferous coals in the Norwegian Barents Sea: Implications for a Palaeozoic petroleum system. Journal of Petroleum Geology, 33, I55-18I.

LARSSEN, G. B., ELVEBAKK, G., HENRIKSEN, L. B., NILSSON, I., SAMUELSBERG, T. J., STEMMERIK, L. and WORSLEY, D., 2005. Upper Palaeozoic lithostratigraphy of the Southern Norwegian Barents Sea. Geological Survey of Norway Bulletin, 444, 3-43.

MARSHALL, C., UGUNA, J., LARGE, D.J., MEREDITH, W., JOCHMANN, M., FRIIS, B.,VANE, C., SPIRO, B.F., SNAPE, C.E. and ORHEIM, A., 20I5. Geochemistry and petrology of Palaeocene coals from Spitzbergen Part 2: maturity variations and implications for local and regional burial models. International Journal of Coal Geology, I 43, I-I0.

MATAPOUR, Z. and KARLSEN, D. A., 2017a. Ages of Norwegian oils and bitumen based on age-specific biomarkers. Petrol. Geosc., 24, 92-101.

MATAPOUR, Z. and KARLSEN, D. A., 20I7b. Geochemical characteristics of the Skrugard oil discovery, Barents Sea, Arctic Norway: a "palaeo-biodegraded - gas reactivated" hydrocarbon accumulation. Journal of Petroleum Geology, $\mathbf{4 0}$ (2), I25-I52.

MATAPOUR, Z., KARLSEN, D.A., LERCH, B. and BACKEROWE, K., 2018. Petroleum occurrences in the carbonate lithologies of the Gohta and Alta discoveries in the Barents Sea,Arctic Norway. Petrol. Geosc., doi.org/ I 0.I I44/ petgeo2017-085.

MØRK,A. andWORSLEY,D., 2006. Triassic of Svalbard and the Barents Shelf. In: Nakrem, H. A. \& Mørk, A. (Eds.), Boreal Triassic. Longyearbyen, Svalbard, I6-19 August 2006. NGF Abstracts and Proceedings of the Geological Society of Norway 3, $149 \mathrm{pp}$.

NILSSON, I., 1993. Upper Palaeozoic Fusulinid stratigraphy of the Barents Shelf and surrounding areas. Unpublished Dr. scient. Thesis, Univ. of Tromsø, Norway, 538 pp.

NPD, Norwegian Petroleum Directorate, 2018. Petroleum resources on the Norwegian continental shelf 2018 Exploration. Electronic document available from: http:// www.npd.no/en/Publications/Resource-Reports/2018/ (accessed on September 4, 20I8).

NYLAND, B., JENSEN, L.N., SKAGEN, J., SKARPNES, O., VORREN, T.O., 1992. Tertiary Uplift and Erosion in the Barents Sea: Magnitude, Timing and Consequences. In: Larsen, R.M. Brekke, H. Larsen, B.T. Talleraas, E. (Eds.), Structural and Tectonic Modelling and its Application to Petroleum Geology. Norwegian Petroleum Society Special Publications, 2, I53-162

NØTTVEDT,A., LIVBJERG, F., MIDBØE, P.S.S. and RASMUSSEN, E., 1993. Hydrocarbon potential of the Central Svalbard Basin. Norwegian Petroleum Society Special Publications, 2, 333-36I.

OGATA, K., SENGER, K., BRAATHEN, A., TVERANGER, J. and OLAUSSEN, S., 2012. The importance of natural fractures in a tight reservoir for potential $\mathrm{CO}_{2}$ storage: a case study of the upper Triassic-middle Jurassic Kapp Toscana Group (Svalbard,Arctic Norway): Geological Society, London, Special Publications, 374, 395-4I5.

PETERS, K. E. and CASSA, M. R., 1994. Applied Source Rock Geochemistry. In: L. B. Magoon, and W. G. Dow (Eds), The petroleum system - from source to trap. AAPG Memoir, 
60, 93-120.

PETERS, K.E. and MOLDOWAN, J.M., I99I. Effects of Source, Thermal Maturity, and Biodegradation on the Distribution and Isomerization of Homohopanes in Petroleum. Organic Geochemistry, I7, 47-5I.

PETERS, K. E., C. WALTERS and MOLDOWAN, J.M., 2005. The Biomarker Guide. Cambridge, Cambridge University Press, 704 pp.

STEEL, R. J. and WORSLEY, D., 1984. Svalbard's postCaledonian strata - an atlas of sedimentational patterns and palaeogeographic evolution. In: A. M. Spencer, (Ed.), Petroleum Geology of the North European Margin:London, Graham \& Trotman, 109-135.

STEMMERIK, L., LARSON, P.A., LARSSEN, G. B., MØRK,A. and SIMONSEN, B. T., 1994. Depositional evolution of lower Permian Palaeoaplysina build-ups, Kapp Duner formation, Bjørnøya,Arctic Norway. Sedimentary Geology, 92, I6I-I74,.

STEMMERIK, L., CHRISTIANSEN, F. G. and PIASECKI, S., 1990. Carboniferous lacustrine shale in East Greenland:additional source rock in the northern North Atlantic? In: B.J. Katz (Ed.), Lacustrine basin exploration: case studies and modern analogs. AAPG Memoir, 50, 277-286.

STEMMERIK, L., 2000. Late Palaeozoic evolution of the North Atlantic margin of Pangea. Palaeogeography, Palaeoclimatology, Palaeoecology, 161, 95-126.

STEMMERIK, L. and WORSLEY, D., 2005. 30 years on - Arctic Upper Palaeozoic stratigraphy, depositional evolution and hydrocarbon prospectivity. Norwegian Journal of Geology, 85, I5I- 168.

VERBA, M. L., 2007. Natural hydrocarbon manifestations in the sedimentary cover of Svalbard. Petroleum Geology -Theoretical and Applied Studies, 2, I-22.

WEISS, H.M., WILHELMS, A., MILLS, N., SCOTCHMER, J., HALL, P.B., LIND, K. and BREKKE, T., 2000. NIGOGA The Norwegian Industry Guide to Organic Geochemical Analyses. Edition 4.0 Published by Norsk Hydro, Statoil, Geolab Nor, SINTEF Petroleum Research and the Norwegian Petroleum Directorate. 102 pp. Electronic document available from www.npd.no/engelsk/nigoga/ default.htm (accessed on January 15, 2018) 